\title{
Effect of Cavity Disinfectants on Dentin Bond Strength and Clinical Success of Composite Restorations-A Systematic Review of In Vitro, In Situ and Clinical Studies
}

\author{
Ana Coelho ${ }^{1,2,3, *,+} \mathbb{D}^{\mathbb{D}}$, Inês Amaro ${ }^{1,+}$, Beatriz Rascão ${ }^{1}$, Inês Marcelino ${ }^{1}$, Anabela Paula ${ }^{1,2,3} \mathbb{D}^{\text {, José Saraiva }}{ }^{1}$,

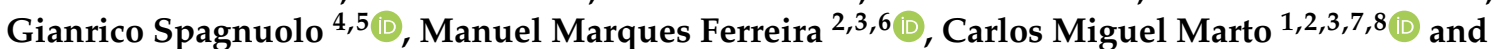 \\ Eunice Carrilho $1,2,3$ (D)
}

1 Institute of Integrated Clinical Practice, Faculty of Medicine, University of Coimbra, 3000-075 Coimbra, Portugal; ines.amaros@hotmail.com (I.A.); beatriznmfrascao@gmail.com (B.R.); inescarvalhomarcelino@gmail.com (I.M.); anabelabppaula@sapo.pt (A.P.); ze-93@hotmail.com (J.S.); cmiguel.marto@uc.pt (C.M.M.); eunicecarrilho@gmail.com (E.C.)

2 Area of Environment Genetics and Oncobiology (CIMAGO), Coimbra Institute for Clinical and Biomedical Research (iCBR), Faculty of Medicine, University of Coimbra, 3000-548 Coimbra, Portugal; m.mferreira@netcabo.pt

3 Clinical Academic Center of Coimbra (CACC), 3004-561 Coimbra, Portugal

4 Department of Neurosciences, Reproductive and Odontostomatological Sciences, University of Naples “Federico II", 80131 Napoli, Italy; gspagnuo@unina.it

5 Institute of Dentistry, I. M. Sechenov First Moscow State Medical University, 119435 Moscow, Russia

6 Institute of Endodontics, Faculty of Medicine, University of Coimbra, 3000-075 Coimbra, Portugal

7 Institute of Biophysics, Faculty of Medicine, University of Coimbra, 3004-548 Coimbra, Portugal

check for updates

Citation: Coelho, A.; Amaro, I.;

Rascão, B.; Marcelino, I.; Paula, A.; Saraiva, J.; Spagnuolo, G.; Marques Ferreira, M.; Miguel Marto, C.; Carrilho, E.; et al. Effect of Cavity Disinfectants on Dentin Bond Strength and Clinical Success of Composite Restorations-A Systematic Review of In Vitro, In Situ and Clinical Studies. Int. J. Mol. Sci. 2021, 22, 353. https://doi.org/ 10.3390/ijms22010353

Received: 13 December 2020 Accepted: 27 December 2020 Published: 31 December 2020

Publisher's Note: MDPI stays neutral with regard to jurisdictional clai$\mathrm{ms}$ in published maps and institutional affiliations.

Copyright: $(\odot 2020$ by the authors. Licensee MDPI, Basel, Switzerland. This article is an open access article distributed under the terms and conditions of the Creative Commons Attribution (CC BY) license (https:// creativecommons.org/licenses/by/ $4.0 /)$.
Institute of Experimental Pathology, Faculty of Medicine, University of Coimbra, 3004-548 Coimbra, Portugal

* Correspondence: anasofiacoelho@gmail.com

+ These authors contributed equally to this work.

Abstract: Cavity disinfection becomes an important step before a dental restorative procedure. The disinfection can be obtained cleaning the dental cavity with antimicrobial agents before the use of adhesive systems. The aim of this study was to conduct a systematic review on the effect of different cavity disinfectants on restorations' adhesion and clinical success. A search was carried out through the Cochrane Library, PubMed, and Web of Science. In vitro and in situ studies reporting results on dentin bond strength tests, and clinical studies published until August 2020, in English, Spanish and Portuguese were included. The methodological quality assessment of the clinical studies was carried out using the Revised Cochrane risk-of-bias tool. Chlorhexidine could preserve adhesion to dentin. EDTA and ethanol had positive results that should be further confirmed. Given the significant lack of scientific evidence, the use of lasers, fluoridated agents, sodium hypochlorite, or other products as cavity disinfectants should be avoided. Chlorhexidine is a safe option for cavity disinfection with adequate preservation of adhesion to dentin. Moreover, future researches should be focused on the efficacy of these disinfectants against cariogenic bacteria and their best application methods.

Keywords: cavity disinfection; antimicrobial substances; chlorhexidine; adhesion; bonding; dental caries

\section{Introduction}

Dental caries is the most prevalent pathology in the oral cavity, affecting most of the world population. Caries results from the interaction between dental structure and microbial biofilm, highly organized and formed on its surface, being characterized by the alternating phenomena of demineralization and remineralization [1-3]. Under pathological conditions, demineralization overcomes remineralization, leading to the dissolution of hard tissues of the tooth, degradation of collagen fibers and impairment of the mechanical properties of dentin, resulting in caries $[1,2,4]$. 
In situations where remineralization is insufficient to resolve the pathology, the treatment of dental caries consists in the removal of infected tissue and subsequent rehabilitation. However, during the removal of decayed tissue, there is the possibility of remaining viable bacteria in the cavity, which can compromise the success of rehabilitation, causing the appearance of a recurrence. On the other hand, rehabilitation failure may be related to tooth and/or restoration fracture and secondary caries, which often occurs at the interface between restorative material and dentin [5-8].

Dentin is considered an intrinsically moist and heterogeneous tissue, which makes adhesion to this tissue a more sensitive adhesive technique when compared to enamel [2,9].

Despite the evolution of adhesive systems, it is known that, over time, the hybrid layer suffers degradation, causing loss of adhesive resistance, which influences the longevity of restorations. The degradation of the adhesive interface is related to several factors, such as oral fluids and bacteria present in situ, leading to degradation of polymers and other organic components. Thus, cavity disinfection becomes an important step prior to the restorative procedure. This is described as cleaning the dental cavity with antimicrobial agents before the use of adhesive systems, making it as innocuous as possible [10].

Among the available disinfectants, chlorhexidine is the most used one. However, despite its beneficial effects, its impact on adhesion is still unclear $[3,10,11]$.

The aim of this study was to conduct a systematic literature review, through the analysis of articles on the effect of different methods of cavity disinfection on adhesion and clinical success of restorations. As so, the research questions were developed according to the PICO (Population, Intervention, Comparison, Outcome) framework-Table 1.

Table 1. Population, Intervention, Comparison and Outcome (PICO) Strategy.

\begin{tabular}{ccc}
\hline Parameter & In Vitro/In Situ & Clinical \\
\hline Population & Teeth or dentin discs & Patients in need of a restoration \\
\hline Intervention & Restoration with prior application of cavity disinfection methods \\
\hline Comparison & \multicolumn{2}{c}{ Conventional restoration } \\
\hline Outcome & $\begin{array}{c}\text { Effect of cavity disinfection on } \\
\text { dentin adhesion (bond strength) }\end{array}$ & $\begin{array}{c}\text { Effect of cavity disinfection on the } \\
\text { clinical success of restoration }\end{array}$ \\
\hline
\end{tabular}

\section{Results}

\subsection{Study Selection}

Initial screening of electronic databases yielded a total of 5645 articles. After removal of duplicated studies, a total of 3967 titles and abstracts were evaluated. Overall, a total of 638 potentially relevant articles were selected after an evaluation of titles and abstracts. Full text of these articles was obtained and thoroughly evaluated, and of these, 154 unique articles filled the inclusion criteria and were subsequently included in the systematic review. Two studies reported results for both in situ and in vitro experiments. The flowchart of the data selection process is presented in Figure 1.

\subsection{In Vitro Studies}

\subsubsection{Study Characteristics}

One hundred and forty-seven in vitro studies were included in this review. Relevant information regarding each one of the studies was collected and can be found in Supplementary Materials S1.

The earliest study was published in 1992 [12] and the most recent ones were published in 2020 [13-18].

Almost all authors stated the use of premolars and/or permanent molars in all experimental procedures except for Yazici et al. [19] that only indicated the use of human teeth without specification on tooth type. The sample size ranged from 2 [20,21] to 20 [22] teeth per group. 
From all of the selected teeth, only dentin substrates were put to use in the experimental protocols and the majority of the authors used healthy dentin as a test substrate. However, some of the authors also used infected dentin [14,23-26] or dentin presenting with artificial caries [27-29] made possible by a laboratory caries-induction procedure. In addition, some studies referred the use of deep and/or superficial dentin [30-38], however in most of the included studies this differentiation was not pointed out.

As regards to the storage medium to preserve teeth after extraction until its use in the experimental procedures, most of the authors reported the use of thymol [15,17,18,25,28,35,36,39-79], chloramine $[13,14,23,26,27,29,30,32-34,38,80-111]$ or water [19-21,31,112-131]. However some other authors chose other storage solutions such as saline solution [22,24,37,132-144], sodium azide [22,135-137,145,146], alcohol [12], sodium hypochlorite [147] or formaldehyde [148]. In nine of the included studies [149-157] there was no available information regarding this issue.
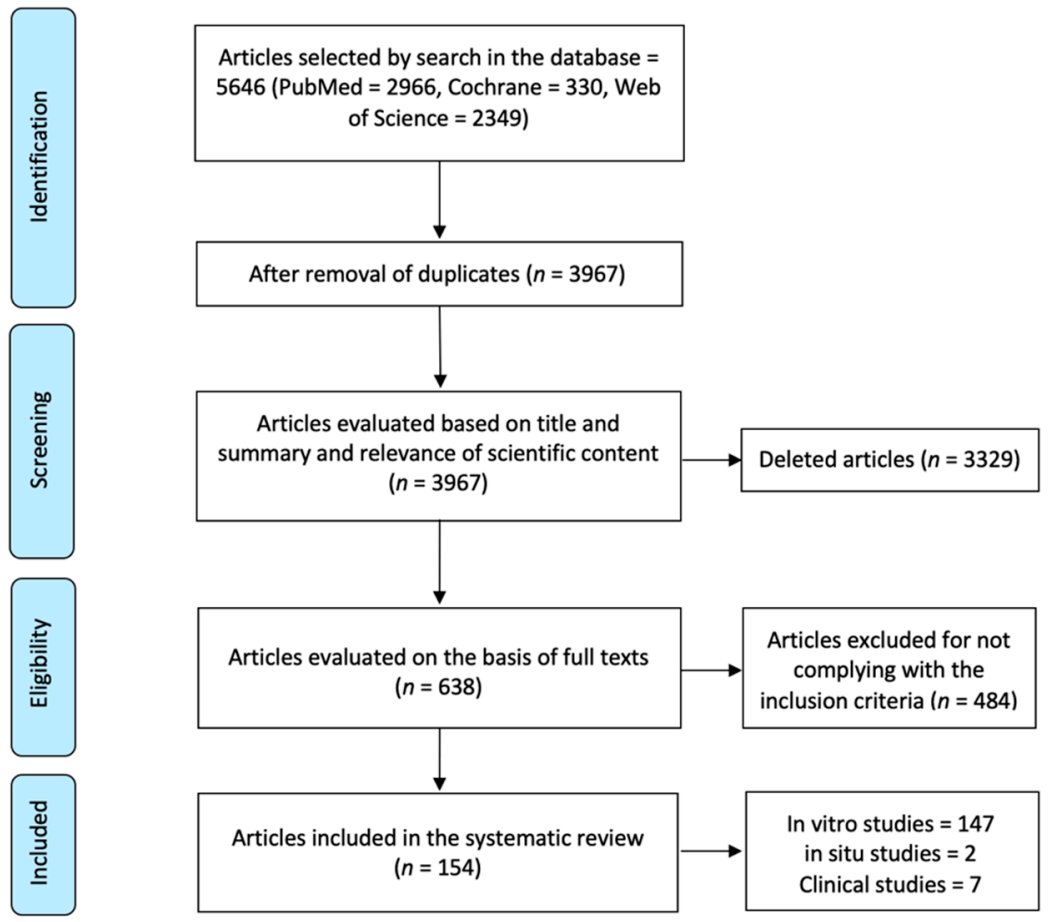

Figure 1. Flowchart of the selection process of the studies.

The majority of the authors $[12-21,23,25-28,30-36,38-41,43-48,50-56,58-61,63-65,67-$ $71,73-97,99-110,112-124,126-137,139-149,152,154,156-158]$ reported the use of water as a storage medium or the incubation of teeth with a $100 \%$ humidity after experimental bonding procedures and before bond strength tests. In some of the studies other options for storage were considered such as artificial saliva $[24,29,49,57,62,111,150]$, saline solution $[37,125]$ and sodium hypochlorite [22]. Six authors [66,72,124,138,151,155] did not provide information on this matter. One of the authors, Silva et al. [98], conducted a study on the effect of chlorhexidine and storage media on bond strength values. The authors used distilled water, mineral oil and sodium hypochlorite as storage media to create three independent groups for each experimental procedure.

\subsubsection{Interventions-Cavity Disinfection Methods}

Most of the studies reported results on the application of cavity disinfectant agents such as chlorhexidine $[12-17,23,24,26,27,36,39,42,53,56,57,61,62,65-70,72,73,75,77,79,81,86-88,90$, 91,98,100,102-105,111,113,122-124,126,128,132-135,137,142,143,147,148,152-155,157], laser systems $[14,19-22,28,29,31,33,37,38,40,41,43,44,46,49-52,54,58,60,63,71,76,78,80,82,83,88,89$, 94-96,101,107,112,114-117,119,120,125,131,139-141,143-145,151,156] and sodium hypochlo- 
rite $(\mathrm{NaOCl})[18,22,25,30,32,34,35,45,47,64,66,70,74,85,90,97,98,106,110,115,118,121,129,130$, $132,138,149,150,152,154,158]$. Further disinfectant solutions were also evaluated in some of the studies: EDTA based solutions [12,23,39,84,100,110,118,130,132,147], fluoridated agents $[28,55,69,74,99,106]$, green tea extract/epigallocatechin gallate (EGCG)/catechin [56, $57,67,136,137]$, ozone $[26,48,93,133,143]$ and ozonated water [93], ethanol [26,59,61,75], tetracyclines [103,104,132,153], hydrogen peroxide [152,154], hypochlorous acid (HOCl) $[25,47]$, boric acid [133,157], silver/zinc/titanium nanoparticles [73,108], aloe vera [65,134], urushiol $[66,70]$, iodine based solutions [127,147,155], proanthocyanidin [53], ferrous sulfate $\left(\mathrm{FeSO}_{4}\right)$ [57], benzalkonic chloride [100], grape seed extract [109] and glutaraldehyde based solutions (Gluma ${ }^{\circledR}$, Kulzer, Hanau, Germany) [13,146].

\subsubsection{Effects of Interventions-Outcomes \\ Chlorhexidine}

The studies evaluating the effects of chlorhexidine as a cavity disinfectant method tested different concentrations, ranging from $0.002 \%$ [86] to $5 \%[23,24]$. However, most of the authors evaluated a $2 \%$ concentration $[13-16,24,26,27,36,39,42,53,56,57,61,62,65-70,73,75,77,79$, 81,87,88,90,91,98,100,102-105,111,122-124,126,128,132-135,137,142,143,147,148,152-155,157].

Regarding its performance as a cavity disinfectant, chlorhexidine presented with positive results in the majority of the studies $[16,17,24,36,39,42,53,56,57,61,62,65-69,72,73,75,77$, $79,81,86,87,90,91,98,100,102-105,111,113,122-124,128,132,134,135,137,142,143,148,153,157]$, allowing for maintenance or even an increase in bond strength values. On the other hand, a few authors $[14,15,26,27,133,154,155]$ reported undesirable results when using chlorhexidine translating in a decrease in bond strength.

Some studies also evaluated the effects of chlorhexidine when combining it with different adhesive systems. Three of the authors [88,147,152] evaluated the effect of pretreatment with chlorhexidine before the application of two different adhesive systems and all of them reported a decrease in bond strength values when using a self-etch system and an increase or maintenance of values when using an etch-and-rinse system when comparing to control groups. On the contrary, Elkassas et al. [132] stated a decrease in bond strength values when using the etch-and-rinse system and an increase when using the self-etch system. However, five studies $[79,113,122,128,137]$ did not find differences in bond strength when comparing the application of self-etch and etch-and-rinse adhesive systems. Sharma et al. [147] still reported that the use of $2 \%$ chlorhexidine before the application of a self-etch adhesive decreased bond strength values but when reducing the concentration to $1 \%$ the authors reported an increase in adhesive forces. Universal adhesive systems were also tested in some of the studies, presenting with positive results regarding bond strength. Say et al. [39] and Campos et al. [42] did not find differences between the use of an etch-and-rinse and a universal system as well as Akturk et al. [157] who also did not find differences between a self-etch and a universal system. Bravo et al. $[123,124]$ also conducted studies testing the three different adhesive systems - etch-and-rinse, self-etch and universal-but find no differences between them. One other author tested the same universal system either as a self-etch or as an etch-and-rinse and concluded that bond strength values increased when using the universal system in etch-and-rinse mode and decreased when using it as a self-etch [102].

\section{Laser Systems}

Twenty-nine studies $[19,28,29,33,37,38,41,43,44,54,58,78,80,82,83,89,94,95,107,112,115-117$, $119,125,140,141,144,145]$ reported the use of the ER:YAG laser, and six [14,50,88,89,96,131] the use of the Er,Cr:YSGG laser. Other laser systems such as the $\mathrm{CO}_{2}[20,49,71,151]$, diode [76,156], Nd:YAP [139], Excimer: KrF [46], ArF [114], Femtosecond [52] and the Ti:sapphire [119] lasers were also reported by some authors although to a lesser extent. 


\section{-ER:YAG LASER}

Ten of the included studies $[19,28,29,38,41,80,94,112,116,125]$ assessing the use of the ER:YAG laser reported a maintenance or increase in bond strength values, even when testing the laser with different working parameters [19,38,94,112]. However, Baraba et al. [95] tested different pulse durations $-50,100$ and $300 \mu \mathrm{s}$ - and reported worse adhesion results for all except for the medium short pulse $(100 \mu \mathrm{s})$. Corona et al. [145] also compared different focal distances $(\mathrm{mm})$ and concluded that adhesion values decreased for all except when the laser was used in a defocused mode $(17 \mathrm{~mm})$. Shirani et al. [58] tested the same variable $-0.5,2,4,11 \mathrm{~mm}$-reporting positive results regarding bond strength but only for the 0.5 and $2 \mathrm{~mm}$ focal distances. Oliveira et al. [54] tested four laser settings (energy/repetition rate) but found no differences between them regarding bond strength alterations.

Nine studies $[33,44,82,83,89,115,117,140,141]$ provided with negative results regarding adhesive forces when comparing to control groups and Gonçalves et al. [33] also reported a decrease in bond strength results when testing either on deep or superficial dentin.

Some of the studies also evaluated the effects of the ER:YAG laser combined with different adhesive procedures. Ramos et al. [78] and OLIVEIRA et al. [54] tested three different systems (self-etch, etch-and-rinse and universal) and reported that bond strength results were favourable when using the self-etch and universal adhesives but decreased when using the etch-and-rinse. Two studies $[43,119]$ evaluated self-etch and etch-and-rinse adhesives being that in the study by Sierpinsky et al. [43], bond strength values decreased for all tested adhesives and in the one by Portillo et al. [119] there was only a decrease when using the etch-and-rinse system.

Two studies $[94,144]$ tested the replacement of phosphoric acid with the laser and also tested its combined action and concluded that when the replacement was performed there was a decrease in adhesion but when used together bond strength values underwent no alterations. Davari et al. [144] also tested the combination of laser + phosphoric acid and reported worse results as well as Alahghemand et al. [37] who described similar results in deep dentin. Kucukilmaz et al. [107] also tested the replacement of phosphoric acid with laser and reported worse results when using the laser.

\section{-Er,Cr:YSGG Laser}

Three studies $[88,96,131]$ reported favourable results regarding this intervention, presenting with the maintenance or increase in bond strength. Chou et al. [131] tested some different laser parameters but reported no differences in adhesion forces for none of them. Çelik et al. [88] tested two adhesive systems-self-etch and etch-and-rinse-applying the laser before the phosphoric acid in the etch-and-rinse system, and also reported positive results for both of them.

However, Ferreira et al. [89] reported negative results with a decrease in bond strength values when applying phosphoric acid followed by laser application. A significant decrease in adhesive forces was also reported by Carvalho et al. [50] who tested a self-etch and an etch-and-rinse adhesive making the replacement of phosphoric acid with the laser in the etch-and-rinse system.

\section{$-\mathrm{CO}_{2}$ Laser}

All four studies $[20,49,71,151]$ assessing this laser as a cavity disinfectant agent reported a decrease in bond strength values when comparing to control groups.

\section{-Nd:YAP Laser}

As for the Nd:YAP laser system, only one study [139] evaluated its effects. The authors did not use any phosphoric acid nor adhesive system together with the laser in none of the experimental groups and reported an immediate decrease in bond strength. 
-Diode

Only two studies $[76,156]$ evaluated the diode laser as a disinfectant method. Zabeu et al. [156] evaluated two adhesive systems, concluding that regarding the etch-and-rinse system (where the laser was applied after the adhesive application) the bond strength values decreased immediately after the procedure and after 12 months. However, when testing the self-etch system these differences were not verified in neither one of the tested time periods. Kasraei et al. [76] reported opposite results since regarding the etch-and-rinse system, bond strength values did not decrease whether the laser was applied before or after the adhesive.

\section{-Excimer: $\mathrm{KrF}, \mathrm{ArF}$}

Regarding the Excimer: $\mathrm{KrF}$ laser, Eugénio et al. [46] reported a decrease in bond strength when the laser was used prior to the phosphoric acid and when it was used as a substitute of the phosphoric acid.

Regarding the Excimer: ArF laser, only one study was included [114] and the authors reported no alterations in bond strength values.

\section{-Femtosecond}

Regarding this intervention, only the study by Gerhardt et al. [52] was included in which different laser parameters were tested and concluded that there was a decrease in adhesive forces when using it at $80 \mu \mathrm{m} / 128 \mathrm{~s}$. However, when using the laser as a substitute of the adhesive primer this decrease was not verified.

-Ti:sapphire

Regarding the Ti:sapphire laser, only one study was included, the one by Portillo et al. [119], in which three adhesive systems were tested-one etch-and-rinse and two self-etch - and the laser was always applied after the adhesive. Favourable results were only achieved when using the one-step self-etch adhesive.

\section{Fluoridated Agents}

Regarding the use of fluoridated agents, studies including the use of solutions such as silver diamine fluoride [28], ammonium hexafluorsilicate [28], sodium fluoride [69], Riva Star (SDI, Victoria, Australia) [99] and titanium tetrafluoride $\left(\mathrm{TiF}_{4}\right)[55,74,106]$ were included.

\section{-Silver Diamine Fluoride and Ammonium Hexafluorsilicate}

As for these disinfection methods, only one study [28] evaluated both of them and concluded that bond strength values decreased when using either of them and when testing in both healthy and artificial caries-affected dentin.

\section{-Sodium Fluoride}

Only one study [69] evaluated this solution as a cavity disinfectant, reporting positive results regarding adhesive forces when used in a concentration of $1.23 \%$.

\section{-Titanium Tetrafluoride}

Three studies $[55,74,106]$ evaluated the effects of $\mathrm{TiF}_{4}$ as a disinfection method. Two of them $[74,106]$ revealed positive outcomes, both using a $4 \% \mathrm{TiF}_{4}$ concentration. In the third study, by Bridi et al. [55], two self-etch systems were tested with a $2.5 \% \mathrm{TiF}_{4}$ concentration and with one of them there was a decrease of adhesive forces.

\section{-Riva Star}

The study by Koizumi et al. [99] was the only study including Riva Star. The authors reported a decrease in bond strength when using both self-etch and etch-and-rinse adhesive systems. 


\section{Sodium Hypochlorite}

The studies evaluating the effects of $\mathrm{NaOCl}$ as a cavity disinfectant tested different concentrations, ranging from $0.5 \%[85,130]$ to $10 \%[18,32,35,45,110,115,121,150]$.

Regarding its action as a cavity disinfectant, $\mathrm{NaOCl}$ performed well in some of the studies, allowing for an increase and / or preservation of bond strength values $[64,74,129,130]$. Kunawarote et al. [25] also reported positive outcomes when testing either in healthy or infected dentin and Aguilera et al. [34] also did not find differences when testing deep nor superficial dentin when using a $5 \% \mathrm{NaOCl}$ solution. However, two studies $[32,35]$ revealed better results when testing a $10 \% \mathrm{NaOCl}$ solution in superficial dentin while another study [30] reported an increase in bond strength when testing a $5 \% \mathrm{NaOCl}$ solution in deep dentin.

Negative results regarding bond strength were also reported $[18,45,70,106,150]$ and one of the studies [150] maintained these results even after 6 months. Kunawarote et al. [47] tested the effects of $\mathrm{NaOCl}$ in different application times $(5,15$ and $30 \mathrm{~s})$ and reported that as the application time increased, the results of adhesive forces worsened, with statistically significant results at $30 \mathrm{~s}$.

Also, some of the studies tested the effect of $\mathrm{NaOCl}$ when used in combination with different adhesive systems, either self-etch $[35,97,118]$, total-etch $[35,115,121]$ and/or universal [118] and all reported positive results regarding bond strength. Abo et al. [85] even tested eight adhesive systems and reported an overall positive outcome immediately after the procedure as well as after 1 year.

Three authors $[92,132,152]$ reported the use of two adhesive systems-self-etch and etch-and-rinse - and achieved opposite results since Mohammad et al. [92] reported a decrease in bond strength values when testing both adhesives, Elkassas et al. [132] reported an increase when using the self-etch and Ercan et al. [152] reported a decrease when using the self-etch. Two other authors $[154,158]$ tested two self-etch adhesives and both also reported an overall decrease in bond strength results.

Prati et al. [138] tested four etch-and-rinse adhesives and reported a decrease in bondstrength for two of them when using a $1.5 \% \mathrm{NaOCl}$ solution. Souza et al. [149] also tested four adhesives, two etch-and-rinse, one self-etch and one universal and reported a decrease in adhesive forces for only one of the etch-and-rinse.

In addition, Wuang et al. [110] reported that when testing a $5 \% \mathrm{NaOCl}$ solution without phosphoric acid the results were unfavourable but when using both there was a positive outcome regarding bond strength. Also, Cha et al. [66] tested the influence of the use of $\mathrm{NaOCl}$ followed or not by a washing step and reported better results when the disinfectant was followed by washing.

\section{EDTA Based Solutions}

Of all the ten studies $[12,23,39,84,100,110,118,130,132,147]$ evaluating the effects of the EDTA based solutions on adhesion, only Wang et al. [110] reported a decrease in bond strength associated with the use of such solutions. The authors tested a concentration of $15 \%$.

\section{Green Tea Extract/EGCG/Catechin}

The green tea extract was evaluated by two studies [57,67] (at concentrations of $0.05 \%$ [57] and $2 \%$ [67]), the EGCG was evaluated by four studies $[56,67,136,137]$ (at concentrations ranging from $0.02 \%[56,136]$ to $5 \%$ [137]) and the catechin by only one study [137]. Of all of the studies evaluating these solutions, only Santiago et al. [56] and Sun et al. [136] reported a decrease in bond strength associated with the use of EGCG but only in a $0.5 \%$ concentration. 
Ethanol

Of all the four studies $[26,59,61,75]$ evaluating the effects of ethanol as a disinfectant agent, only Ozsoy et al. [26] described a decrease in bond strength but only when testing in caries-affected dentin.

Ozone

The use of ozone as a cavity disinfectant was reported in five of the included studies $[26,48,93,133,143]$. Garcia et al. [93] and Ercan et al. [133] did not report a decrease in bond strength regarding restorations performed in ozone disinfected cavities. However, Rodrigues et al. [48] reported a decrease in bond strength when the ozone was either used after or before the phosphoric acid application, describing a higher decrease in the latter. Dalkilic et al. [143] reported similar results as well as Ozsoy et al. [26] either in healthy or infected dentin.

Boric Acid

Boric acid was reported in two of the studies [133,157]. Akturk et al. [157], which evaluated its effects on adhesion when using it before a self-etch or a universal adhesive system, reported that there was a decrease in bond strength only when the boric acid was used before the universal system. However, Ercan et al. [133] reported a decrease in bond strength when testing the boric acid with a self-etch adhesive.

Iodine Based Solutions

Silva et al. [127], Sharma et al. [147] and Suma et al. [155] evaluated the effect of iodine based solutions on adhesion and all authors reported a decrease in bond strength in the majority of test conditions.

Hydrogen Peroxide

Two studies [152,154] evaluated the effects of 3\% hydrogen peroxyde as a cavity disinfectant. Ercan et al. [152] evaluated the use of hydrogen peroxide when using an etch-and-rinse and a self-etch adhesive system. The authors described a decrease in bond strength associated with the use of the self-etch system. Reddy et al. [154] tested two self-etch systems and reported a decrease in bond strength for both adhesives.

\section{Benzalkonic Chloride}

Tekçe et al. [100] evaluated the effect of $1 \%$ benzalkonic chloride on adhesion $24 \mathrm{~h}$ and 12 months after the adhesive procedure. The authors reported a decrease in bond strength only at 12 months.

Other Disinfectant Methods

Urushiol [66,70], doxycycline [103,153], minocycline [104,153], glutaraldehyde based solutions $\left(\right.$ Gluma $\left.^{\circledR}\right)[13,146]$, hypochlorous acid [25,47], ferrous sulfate [57], proanthocyanidin [53], ozonated water [93], grape seed extract [109], silver/zinc/titanium nanoparticles $[73,108]$ were all evaluated in only one or two studies and none of the products was associated with a decrease in bond strength in none of the test conditions. The effects of BioPure (Dentsply Sirona, York, PA, USA), a tetracycline based solution, were only reported by Elkassas et al. [132], who tested two distinct adhesive systems. The authors described an increase in bond strength after cavity disinfection with BioPure when used with an etch-and-rinse adhesive system. However, when using a self-etch system the bond strength decreased. 


\subsection{Clinical Studies}

\subsubsection{Study Characteristics}

Seven clinical studies were included in this review and relevant information regarding each one can be found in Supplementary Materials S2. All of the studies are classified as RCT being that four have a split-mouth design [159-162] and one is a pilot study [163].

The earliest study was published in 2006 [163] and the most recent one was published in 2020 [164].

The number of included participants ranged from $11[163]$ to $42[159,160]$ patients over 20 years old. The sample size ranged from 41 [163] to 169 [160] non-carious cervical lesions. All authors used relative field isolation except for Torres et al. [162] who used absolute field isolation. The follow-up period ranged from 6 months [160] to 5 years [162].

\subsubsection{Interventions-Cavity Disinfection Methods}

All of the clinical studies selected for inclusion in this review were analyzed and four of them reported the use of $2 \%$ chlorhexidine [159-161,165], two reported the use of $10 \%$ $\mathrm{NaOCl}[162,163]$ and one reported the use of the diode laser [164].

\subsubsection{Clinical Outcomes}

Several clinical aspects were assessed and used to withdraw conclusions regarding the effects of each disinfectant. All the clinical studies evaluated postoperative sensitivity, retention of the restoration and marginal discoloration. Presence or absence of secondary caries was evaluated by all authors except for Montagner et al. [160] and Favetti et al. [159]. Marginal integrity/adaptation was also evaluated by all except for Saboia et al. [163]. Pulp vitality was only evaluated in four of the included studies [159-162]. Other clinical aspects such as preoperative sensitivity [165], wear [165], clinical success [160,161], dental integrity [159,160], periodontal health [160] and survival rate [159] were only evaluated in one or two studies.

\subsubsection{Effects of Interventions-Outcomes}

Dutra-Correa et al. [165], Montagner et al. [160] and Favetti et al. [159] tested a 2\% chlorhexidine solution and didn't find statistical differences at baseline and after follow-up regarding the clinical aspects assessed in each study. Saboia et al. [163] tested $\mathrm{NaOCl}$ at a $10 \%$ concentration and also reported no statistical differences regarding clinical outcomes either at 12 or 24 months. Torres et al. [162] also tested a 10\% $\mathrm{NaOCl}$ solution and Akarsu et al. [164] tested a diode laser and both reported worse clinical results when comparing to baseline after 5 years and 18 months, respectively, however without statistically significant differences.

The only study presenting with statistically significant differences was the one by Sartori et al. [161] in which $2 \%$ chlorhexidine was evaluated. There was a statistically significant difference between the 12 and the 36 months recall for the experimental group regarding marginal discoloration. This difference was also verified between the baseline and the 36 months recall for both experimental and control groups. There was also a statistical difference between the baseline and the 36-month follow-up for the experimental group regarding retention and clinical success.

Of the four studies [159-162] evaluating pulp vitality, all reported a $100 \%$ success rate. The same percentage applied for the results regarding periodontal health, evaluated in only one study [160].

\subsection{In Situ Studies}

Only two in situ studies [61,122] were included in this review.

Simões et al. [61] evaluated the influence of chlorhexidine and ethanol on bond degradation. The authors compared the bond strength of an etch-and-rinse adhesive system at $24 \mathrm{~h}$ and 6 months (in vitro study) and in an in situ cariogenic challenge with nine patients aged $20-50$ years. The bond strength values of the sticks submitted to the in 
situ cariogenic challenge were similar to those reported for the in vitro experience and the authors concluded that chlorhexidine and ethanol did not affect the bond strength.

Gunaydin et al. [122] evaluated the effect of $2 \%$ chlorhexidine on the immediate and aged dentin bond strength of one etch-and-rinse adhesive system and three selfetch adhesive systems in an in vitro and in an in situ experiment. For the in situ study, 40 patients aged 23-28 years were enrolled. Regardless of the adhesive system used, chlorhexidine treated groups exhibited lower immediate bond strength values and higher aged dentin bond strength values.

\subsection{Assessment of Methodological Quality}

The results of the studies' quality assessment are presented in Figure 2.

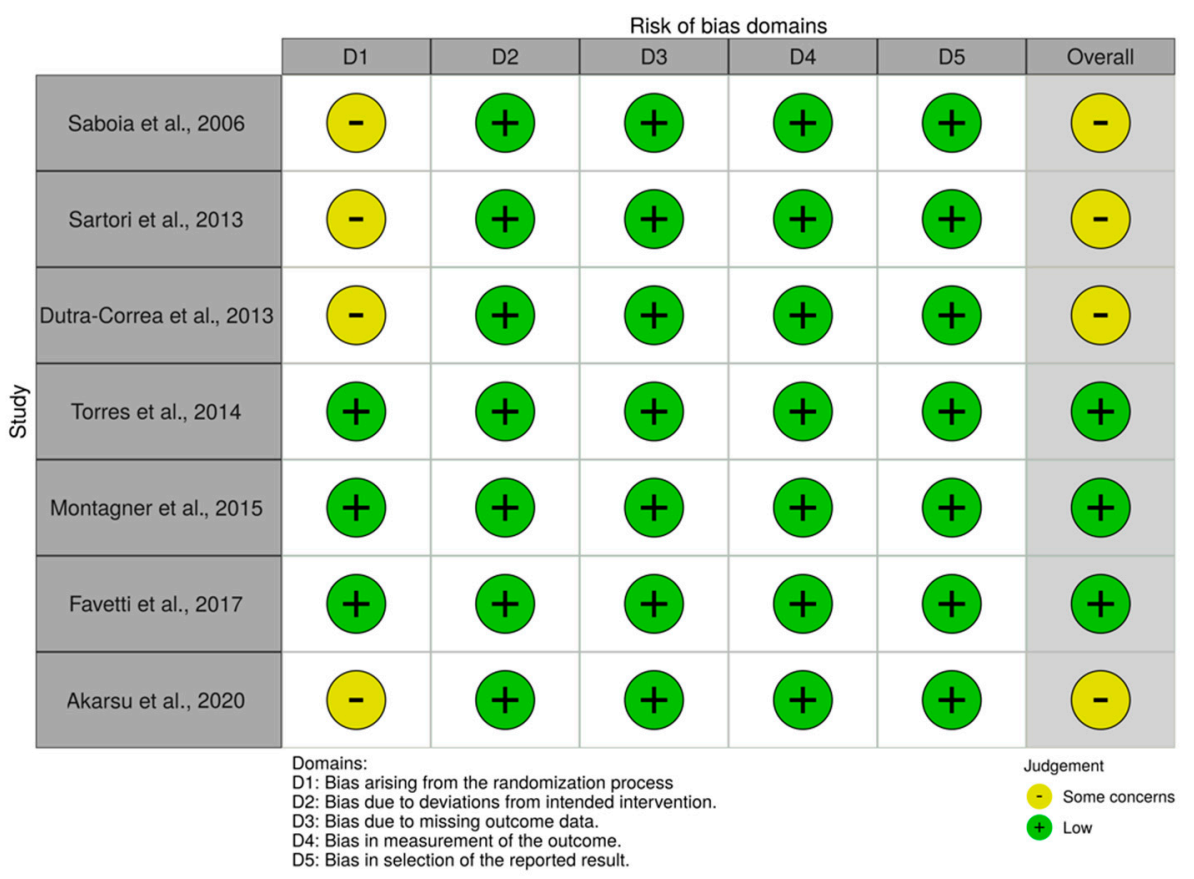

Figure 2. Methodological quality assessment of the included clinical (RCT) using the Revised Cochrane risk-of-bias tool for randomized trials (RoB 2).

Three studies presented an overall classification of "low" risk of bias while four studies presented with "some concerns". These four studies all presented with insufficient information regarding the first domain as regards to the randomization process in which all of them failed to mention whether or not the allocation sequence was concealed until participants were enrolled and assigned to interventions. All of the other domains in all the included studies were well described.

\section{Discussion}

A cavity disinfectant must be bactericidal and/or bacteriostatic, biocompatible and easy to acquire and handle. It needs to be capable of correctly disinfecting the cavity but without compromising dentin bond strength. Its effect depends on each disinfectants characteristics but also on the type of substrate, adhesive system and restorative material used $[90,108,126]$.

Dental substrates play an important role in the performance of adhesive systems, since the morphological and chemical-mechanical characteristics of healthy dentin are different from those of caries affected dentin [138]. The intertubular dentin of a caries affected substrate is partially demineralized, resulting in a softer and more porous structure, which compromises the adhesive strength $[25,27,28]$. Moreover, differences between superficial and deep dentin are also identified. Superficial dentin, composed mainly of intertubular 
dentin, has a higher percentage of collagen and a smaller number of dentinal tubules. The deep dentin, close to the pulp region, is formed mainly by dentinal tubules and presents a reduced percentage of intertubular dentin, mainly after acid etching $[32,36,78,136]$. As so, deep dentin is more hydrophilic, making disinfectants much more efficient in superficial dentin. In fact, several authors confirmed that adhesion to superficial dentin was significantly higher than that in deep dentin [30-33,37,38].

In most of the selected in vitro studies, the samples were placed in a storage medium before being submitted to adhesive resistance tests, in order to simulate the clinical aging of a material overtime. The ISO/TS 11405:2015 (Dental materials - testing of adhesion to tooth structure) [166] gives guidance on substrate selection, storage and handling of samples for quality testing of the adhesive bond between restorative materials and tooth structure. This ISO suggests distilled water or a $0.5 \%$ chloramine solution as good storage media for a maximum of one week after which the samples should be kept in distilled water at the temperature of $4{ }^{\circ} \mathrm{C}$ or under $-5^{\circ} \mathrm{C}$. No other chemical agents should be used since it might affect absorption, adsorption, diffusion, and dissolution, and consequently alter the physical properties of dentin [167]. Furthermore, the longer the storage time, the worse the mechanical properties of the teeth (such as decreased microhardness and negative influence on bond strength) [168-170].

Although most studies reported the use of distilled water or chloramine as a storage medium, following the recommendations of the ISO, there were several authors using other solutions, such as thymol, which was used in 48 studies $[15,17,18,25,28,35,36,39-79]$.

Given the degenerative changes that take place in dentin proteins, after teeth extraction the ISO/TS 11405:2015 [166] states that when it is not possible to perform experimental procedures immediately after teeth extraction, these should be performed in a time period not superior to 6 months. After the conclusion of all restorative procedures, the samples should be kept in water (ISO 3696:1987, grade 3 [171]) at a temperature of $23^{\circ} \mathrm{C}$.

The ISO/TS 11405:2015 [166] also states that ideally premolars and permanent molars should be used being also preferable to use third molars from individuals with ages ranging from 16-40 years. Almost all authors stated the use of premolars and/or permanent molars except for Yazici et al. [19] that only indicated the use of human teeth without specification on tooth type. However, it was not possible to obtain information regarding the age of the patients.

Regarding disinfectants, there are many available products in the market. In this review only studies that tested, at most, one cavity disinfection method per experimental group were included as a way to try to perceive each disinfectant's true effect regarding bond strength alterations. In addition, experimental disinfectants were not considered.

\subsection{In Vitro Studies}

Chlorhexidine has a broad spectrum of antibacterial action, specially against grampositive bacteria, and is used in different medical fields. Of all the species implicated in dental caries, epidemiologic evidence associates Streptococcus mutans as the main initiator of dental caries and it is known that chlorhexidine has a strong antibacterial capacity against it. Chlorhexidine also has the ability to inhibit the formation of the acquired pellicle, acting as an antiplaque agent [172-178].

As for the studies included in this review, most of the studies reported a maintenance or even an increase in bond strength values when chlorhexidine was used before the adhesive system, regardless of the concentration tested. Although some authors have studied the use of different adhesive systems (etch-and-rinse, self-etch and universal) after disinfection of the cavity with chlorhexidine, there seems to be no differences between them.

The enzymatic degradation of the collagen matrix by host-derived enzymes plays a significant role in destroying adhesive interfaces. Chlorhexidine is able to inhibit those collagen-degrading enzymes (namely matrix metalloproteinases (MMP) and cysteine cathepsins) which may justify the positive results [179-181]. On the other hand, chlorhexi- 
dine seems to have the ability to remove the loose smear debris and to increase the surface energy of dentin, which increases the wetting ability of primers [132,182].

The results are mainly positive and the pretreatment with chlorhexidine demonstrated an adequate preservation of adhesion to dentin, which makes it a safe option for cavity disinfection.

Another possible cavity disinfection method is laser irradiation. According to some authors, irradiation of the dentin surface results in improved microhardness, increased resistance to demineralization and decreased dentin permeability, minimizing bacterial access to the pulp $[20,40,88]$.

However, the results regarding the use of lasers as cavity disinfectants are not consistent, with almost half of the studies reporting that lasers exert a negative effect on the mineral and organic components of dentin, impairing adhesion force [78,183,184].

The Erbium-doped yttrium aluminum garnet (Er:YAG) laser is widely used in different medical fields and has the highest water absorbency which makes it well absorbed in biological tissues containing water. This laser was the most studied one but the results are contradictory, regardless of the laser parameters and the adhesive system used. Dunn et al. [83] reported large peritubular areas with scaling and flaking aspects as well as a defective hybridization between dentin and composite resin when the surface was irradiated before acid-etching, which may justify the negative results. The residual thermal energy can also influence bonding by modifying the hydroxyapatite crystals, denaturing the collagen fibers and excessively dehydrating dentin $[31,33,89,145,185,186]$.

Since laser ablation promotes opening of the dentinal tubules, some authors tested it as an alternative to acid-etching. However, bond strength values decreased in all studies $[19,29,37,38,43,44,54,58,78,80,83,94,95,116,117,119,125,140,141,144]$. One possible explanation for the negative results is that the Er:YAG laser doesn't demineralize the peritubular dentin, which may hamper the formation of a hybrid layer and resin tags [31,187].

Regarding the other lasers included in this analysis (Er,Cr:YSGG, $\mathrm{CO}_{2}, \mathrm{Nd}$ :YAP, diode, Excimer: $\mathrm{KrF}$ and $\mathrm{ArF}$, femtosecond, Ti:sapphire) the number of articles that reported results on them is very small. Since different lasers, with different parameters and under different conditions are used, it is not possible to draw conclusions.

Given the significant lack of scientific evidence, the use of lasers as cavity disinfectants should be avoided.

Some materials, such as fluoridated agents, are indicated for dentin pretreatment for different purposes [55]. These products help to diminish the development of secondary caries by decreasing dentin solubility and enhancing dentin remineralization [55,74]. Fluoridated agents such as silver diamine fluoride, ammonium hexafluorsilicate, sodium fluoride, titanium tetrafluoride $\left(\mathrm{TiF}_{4}\right)$ and Riva Star were included in this review and its effects as cavity disinfectants prior to adhesive procedures and the influence in bond strength values were analysed. The results were mostly positive with reports of maintenance or even increase the bond strength in four out of six studies—sodium fluoride [69] and titanium tetrafluoride $[55,74,106]$.

Metal fluorides, especially titanium tetrafluoride, have become popular due to their unique interaction with dental hard tissues [106]. In fact, $\mathrm{TiF}_{4}$ was the most studied fluoridated disinfectant agent, with a total of three studies which reported mostly positive results regarding bond strength. Its beneficial effects can be attributed to the increase of fluoride uptake, which can chemically reduce demineralization of dental hard tissues, but also to the formation of an acid-stable surface layer, referred to as glaze-like layer [188], which provides mechanical protection of the surface, forming a fine layer of titanium containing material, covering the surface and occluding the dentinal tubules $[189,190]$. However, one of the erosions' inhibiting characteristics of $\mathrm{TiF}_{4}$ depends on its method of application on dentin. It seems that application with a microbrush leads to surface wear rather than allowing the formation of the glaze-like surface layer [191]. In all of the three included studies which tested $\mathrm{TiF}_{4}$, the product was actively applied with a microbrush for 
$60 \mathrm{~s}$, which may possibly justify why pretreatment with $\mathrm{TiF}_{4}$ had no negative effects on bond strength.

Nevertheless, there was only a total of six studies regarding the use of fluoridated agents as cavity disinfectants and only three evaluating $\mathrm{TiF}_{4}$, which makes it unadvisable to recommend its use until further studies are conducted on the matter to prove its feasibility.

Sodium hypochlorite is one of the most commonly used cavity disinfectants in clinical practice due to its antibacterial action and wettability property [132]. It also has the highest antimicrobial activity against anaerobic bacteria, as well as against Streptococcus mutans $[66,192,193]$.

As regards to its use in restorative protocols, sodium hypochlorite has been considered for use prior to adhesive procedures as a cavity disinfectant. However, as for the studies' results, there is a lack of consensus since some authors $[64,74,129,130]$ reported positive results with maintenance or increase of bond strength values and others $[18,45,70,106,150]$ reported a decrease. These differences might be attributed to differences in experimental protocols such as different $\mathrm{NaOCl}$ concentrations, adhesive systems and dentin substrates. Also, the decreased bond strength values may also be due to the oxygen released by $\mathrm{NaOCl}$ molecules as it may inhibit adhesive polymerization and compromise the mechanical performance of the bonding interfaces [32].

The substrate plays an important role on the adhesion of current adhesive systems and, in this case, four studies [30,32,34,35] evaluated the effects of sodium hypochlorite demineralization on deep and superficial dentin. Although one study [34] did not find differences when testing deep nor superficial dentin when using a $5 \% \mathrm{NaOCl}$ solution, two other studies $[32,35]$ revealed better results when testing a $10 \% \mathrm{NaOCl}$ solution in superficial dentin. Since there are morphological differences between these two substrates, this might occur due to a decrease in the area of intertubular dentin available for bonding in deep dentin [30]. Furthermore, failure in removing all residual water confined deep into demineralized surfaces induces the formation of poorly polymerized polymer chains [34]. In addition, lower concentrations and times of application promote a continuous and slow denaturation of dentin collagen, leading to the formation of a gel layer on the demineralized dentin, preventing the diffusion of adhesive monomers. As the concentration and the time of application increases, denaturation progresses to degradation and complete dissolution of collagen, increasing the porosity of the dentin surface and diffusion of adhesive monomers through demineralized dentin [194]. This may also justify the results since a higher concentration of $\mathrm{NaOCl}-10 \%$ - was used in those two studies. Only one study [30] reported an increase in bond strength when testing in deep dentin with a 5\% $\mathrm{NaOCl}$ solution. According to the authors, the total or partial removal of the collagen layer in the deep dentin by sodium hypochlorite may facilitate the penetration of the adhesive and avoid adhesive failures on deep cavities.

Some studies also evaluated the use of sodium hypochlorite in combination with different adhesive systems (etch-and-rinse, self-etch and/or universal) but there was no obvious consensus amongst authors since results were very incoherent making it impossible to draw conclusions regarding this matter.

There is no clear evidence on the effects on bond strength when using sodium hypochlorite as a cavity disinfectant prior to adhesive procedures and so caution is required until further studies assure its effects.

Ethylenediamine tetraacetic acid (EDTA) is an organic compound, capable of chelating calcium ions and selectively removing hydroxyapatite without entering deeply into the dentinal tubules [110]. It is an MMP inhibitor solution capable of increasing the longevity of the adhesive interface, dissolving the mineral components of dentin without altering the stability of the organic matrix and without causing collagen denaturation [23,84].

Nine $[12,23,39,84,100,118,130,132,147]$ out of the ten studies evaluating the effects of EDTA reported maintenance or even an increase on mean bond strength despite the adhesive system used (etch-and-rinse, self-etch or universal). Although there is a need for 
further studies, the use of EDTA based solutions as cavity disinfectants prior to adhesive procedures seems to be a favorable alternative.

Ethanol is another possible alternative as a cavity disinfection method since when applied to dentin cavities it has the ability to expel water from dentin, keeping the collagen network distended. The interfibrillar spaces in the collagen matrix are filled with ethanol and the exposed collagen fibers are involved, preventing its degradation by MMP, thus providing a better substrate for resin placement and monomer infiltration [26,75]. It is also able to create a more hydrophobic environment, reducing water absorption over time, which is a key factor in the degradation of the adhesive bond [75]. This is in line with the results from the included studies since out of all the four studies [26,59,61,75] evaluating the effects of ethanol, only Ozsoy et al. [26] described a decrease in bond strength but only when ethanol was tested in caries-affected dentin. This substrate has a high degree of porosity due to mineral loss and partial or total tubular obstruction in the intertubular area which may justify these results. In addition, adhesive systems cannot infiltrate as deeply into demineralized intertubular structures as acids can, resulting in lower bond strength values than when testing in healthy dentin [26].

Since a decrease in bond strength was only observed when testing in caries-affected dentin [26] and since this is a more complex substrate for adhesion but also the main purpose of using cavity disinfectants, more studies should be conducted testing ethanol in caries-affected dentin to assess its feasibility when attempting to disinfect this substrate. Even though there is limited information about the use of ethanol as a cavity disinfectant, from the available results it looks like a promising alternative.

Ozone is a naturally occurring compound of three oxygen atoms. It is a strong oxidizing agent, with antibacterial activity capable of disrupting the cell wall and cytoplasmic membrane of microorganisms [157], which allows it to efficiently eliminate bacteria, fungi, protozoa, and viruses $[48,143]$.

Ozone has also been proposed as a cavity disinfection method prior to restorative procedures since due to its oxidative and antimicrobial activity, it has the capacity to oxidize proteins in carious lesions and consequently diffusing and depositing calcium and phosphate ions into the demineralized dental tissues, hence leading to remineralization [48, 143]. However, the results of the five included studies regarding the use of ozone are inconsistent since two authors $[93,133]$ did not report a decrease in bond strength and the other three authors $[26,48,143]$ reported opposite results even when testing either in healthy or infected dentin $[26,143]$. This might be due to the fact that ozone is an unstable molecule and rapidly dissociates into oxygen molecules which will react with free radicals and may cause the inhibition of polymerization of adhesive systems and thus reduce bond strength $[26,48]$. Therefore, the decrease in bond strength values may have been caused by the presence of residual oxygen molecules after the use of ozone. However, this is not in accordance with the results by Rodrigues et al. [48] who reported a higher decrease when ozone was used before rather than after the use of phosphoric acid which was immediately followed by the adhesive system. The authors stated that the results could only be justified by some chemical interaction that might have occurred between ozone and phosphoric acid, when the acid was used after the ozone, which interfered directly with the formation of the hybrid layer and might therefore affect the bond strength [48].

The use of ozone as a cavity disinfection method is still a matter of discussion since there is yet little available information on its effects on bond strength.

Some other disinfectant agents such as urushiol [66,70], tetracyclines [103,104,132,153], glutaraldehyde based solutions [13,146], hypochlorous acid [25,47], ferrous sulfate [57], proanthocyanidin [53], ozonated water [93], grape seed extract [109], silver/zinc/titanium nanoparticles $[73,108]$, aloe vera $[65,134]$ and green tea extract/EGCG/catechin $[56,57,67$, 136,137] were included in this review, although to a lesser extent. Even though none of these products was associated with a decrease on bond strength in the majority of the test conditions, only a very limited number of studies regarding each disinfectant were included. On the other hand, other disinfectants such as boric acid [133,157], benzalkonic 
chloride [100], iodine based solutions [127,147,155] and hydrogen peroxide [152,154] were not only evaluated in very few studies but also all of them reported a decrease in bond strength in most of the experimental scenarios. Being that, the use of these products should be handled with caution since there is insufficient scientific evidence to support its use as cavity disinfectants.

In addition, there are several studies experimenting with different adhesive systems, given the different methodological approaches and reported results it is not possible to draw conclusions.

The development of new quality in vitro studies is essential. Although there is a lack of a standardized protocol, the experiments should account in detail for storage media and conditions, studied dental substrates, control and test groups, outcome measurement, and limited variables (e.g., the use of more than a cavity disinfectant per experimental group doesn't allow the evaluation of its true effect on bond strength).

\subsection{Clinical Studies}

Concerning the clinical studies, the results were mainly positive for all tested disinfectants. Only Sartori et al. [161] reported worse results with statistically significant differences when testing a $2 \%$ chlorhexidine solution. The authors reported a statistically significant difference between the 12 and the 36 months recall for the experimental group regarding marginal discoloration and also between the baseline and the 36 months recall for both experimental and control groups. One possible explanation is the hypothesis that the repetitive cyclic of parafunctional loadings might have induced a failure in the cervical region of the restoration which might have generated micro-cracks at the restoration margin [161]. There was also a statistical difference between the baseline and the 36-month follow-up for the experimental group regarding retention and clinical success. These results might be due to the fact that despite chlorhexidine could decelerate the rate of resin-dentin bonds degradation by inhibition of MMP, it could not prevent the hydrolytic breakdown of polymers that constitute those bonds. Also, another aspect that could not be clarified in the study by Sartori et al. [161] is the origin of the adhesive failures, whether the negative results were due to a defect within the resin or the dentin matrix part of the hybrid layers.

Even though results concerning these disinfectants were mostly positive there is a clear need for further clinical studies regarding these and other disinfectant alternatives and with longer follow-up periods. According to the American Dental Association [195], it is required a retention rate of at least $90 \%$ of the restorations placed after 18 months to obtain full acceptance. Given this guideline, the study by Dutra-Correa et al. [165] achieved full acceptance since after 18 months the retention rate was over $90 \%$ when testing a $2 \%$ chlorhexidine solution. Torres et al. [162] reported a $97 \%$ retention rate after 18 months but not after 3 nor 5 years. Saboia et al. [163] also reported a 90\% retention rate after 24 months but only for one of the tested adhesive systems.

According to the American Dental Association guidelines [195], non-carious cervical lesions are ideal models for testing the bonding of restorative materials to dental tissue. This is due to the non-carious loss of dental hard tissue having the most of the bonding area in dentinal tissue with only a small incisal/occlusal margin in enamel, they do not have a retentive shape and do not require preparation before restoration. However, the causes of the diminished longevity of non-carious class $\mathrm{V}$ restorations are still poorly understood, in contrast with other restorations [159-161] since they are known to have a multifactorial etiology and the prognosis may be significantly affected by several factors related to the material, patient and the environment [160]. The oral environment presents a challenge to the longevity of adhesive resistance since there are several factors that can influence the long term success of restorations such as temperature changes, masticatory load cycles, water absorption and $\mathrm{pH}$ fluctuations [196]. It is also important to consider that these kind of lesions might be due to characteristics of an individual patient (for example, 
parafunctional habits) [159-161] and so it is important to consider patient's individual characteristics since these might affect the survival of restorations.

In order to reduce the impact of these variations on the studies, a good alternative might be to use a split-mouth design which was used in four of the included studies [159-162]. Also, different teeth cavity configurations [161] and each lesions' different clinical characteristics $[159,160]$ should also be taken into account since these might turn substrates more complex to adhesive procedures [159,160] — enamel, dentin or sclerotic dentin [159,160,165]. In the study by Montagner et al. [160] some cavity variables affected the retention of the cervical restorations regardless of the treatment since deeper and wider lesions presented statistically more retention failure than the others. On the other hand, the effect of cavity configuration and location of the restoration margin in relation to the gingival margin were not significant factors for restoration retention in the study by Favetti et al. [159].

A summary of the available evidence on each cavity disinfectant is presented in Table 2.

Table 2. Summary table of the available evidence on the use of cavity disinfectants.

\begin{tabular}{|c|c|}
\hline Disinfectant & $\begin{array}{l}\text { Does the Available Evidence Support Its Use as } \\
\text { a Cavity Disinfectant? }\end{array}$ \\
\hline Aloe vera & No (limited number of studies) \\
\hline Benzalkonic chloride & No \\
\hline Boric acid & No \\
\hline Chlorhexidine & Yes \\
\hline EDTA & Yes (positive results but limited number of studies) \\
\hline Ethanol & No (limited number of studies) \\
\hline Ferrous sulfate & No (limited number of studies) \\
\hline Fluoride & Yes (positive results but limited number of studies) \\
\hline Glutaraldehyde & No (limited number of studies) \\
\hline Grape seed extract & No (limited number of studies) \\
\hline Green tea extract/EGCG/catechin & No (limited number of studies) \\
\hline Hydrogen peroxide & No \\
\hline Hypochlorous acid & No (limited number of studies) \\
\hline Iodine & No \\
\hline Laser & No \\
\hline Ozonated water & No (limited number of studies) \\
\hline Ozone & No \\
\hline Proanthocyanidin & No (limited number of studies) \\
\hline Silver/zinc/titanium nanoparticles & No (limited number of studies) \\
\hline Sodium hypochlorite & No \\
\hline Tetracyclines & No (limited number of studies) \\
\hline Urushiol & No (limited number of studies) \\
\hline
\end{tabular}

The main limitations of the included studies concerns the randomization process in which four of the studies [161,163-165] failed to mention whether or not the allocation sequence was concealed until participants were enrolled and assigned to interventions. Also, the field isolation is an important aspect to consider when performing adhesive procedures and since all authors used relative field isolation except for Torres et al. [162], who used absolute field isolation, this is also an important limitation. Restoration losses of non-carious cervical lesions are more prevalent in the posterior region due to stress 
intensity and moisture contamination in the cervical region which justifies the importance of absolute field isolation [164].

As so, there is a clear need for further clinical studies regarding this topic that allow the adoption of strict inclusion criteria, the generation of random sequences and the use of blind participants, examiners and evaluators. There is also a need for longer follow-up periods, in order to assess whether these products can be incorporated into restorative protocols or not.

\section{Materials and Methods}

This systematic review was registered on the International Prospective Register of Systematic Reviews (PROSPERO) platform (temporary ID: 199614) and designed according to PRISMA methodology (Preferred Reporting Items for Systematic Reviews and Meta-Analysis).

\subsection{Inclusion and Exclusion Criteria}

In vitro, in situ and clinical studies evaluating the effect of applying, at most, one cavity disinfection method per experimental group and evaluating the effect of the disinfection method on dentin adhesion of commercially available conventional adhesives and composites were included. Only in vitro and in situ studies reporting results for bond strength tests, presented in the form of mean and standard deviation, were considered.

Clinical studies on postoperative sensitivity, marginal pigmentation and adaptation, restoration loss, secondary caries, microinfiltration and pulp vitality were included.

Studies with no control group, in deciduous teeth, in bleached teeth or in teeth with endodontic treatment were excluded. Studies evaluating the adhesion of posts, cements, sealants, brackets or glass ionomer, studies that used manipulated adhesives (experimental or mixed with other solutions) and studies evaluating root or pulp chamber walls were also excluded. Regarding the laser, the studies that used it to prepare the cavity and not only as a disinfection method were also excluded. Previous contamination of teeth with hemostatic agents, saliva or blood was also considered an exclusion criterion.

All review articles, cell or animal studies, letters, case reports, abstracts and comments were excluded.

\subsection{Search Strategy}

An electronic search was carried out in the Cochrane Library (www.cochranelibrary. com), PubMed (www.ncbi.nlm.nih.gov/pubmed) and Web of Science (www.webofscience. com) databases, by articles published until August the 8th of 2020, without restrictions on the type, region or year of publication. Only articles in English, Portuguese and Spanish were included. Articles that weren't available online were excluded.

For the research, the terms MeSH "Dentin", "Disinfection", "Anti-Bacterial Agents", "Chlorhexidine", "Sodium Hypochlorite", "Lasers", "Ozone", "Ethanol", "Aloe" and "Adhesives" were used. The search keys used in the different databases are found in Table 3.

\subsection{Study Selection}

The eligibility of the initially selected articles was evaluated by reading titles, abstracts and full text by two reviewers, independently. Any disagreement was discussed and the opinion of a third reviewer was obtained when necessary.

\subsection{Data Extraction}

Selected articles were read independently by two reviewers. During data extraction, two Microsoft ${ }^{\circledR}$ Excel (Microsoft, Washington, WA, USA) tables were elaborated. The first, for the in vitro studies, included the parameters: name of the authors, year of publication, groups (n), storage solutions and materials used, and results (bond strength). The second table, for the in vivo studies, included the parameters: name of the authors, year of publication, type of study, groups (n), follow-up period, materials used, and re- 
sults. Any disagreement was discussed and the opinion of a third reviewer was obtained when necessary.

Table 3. Search keys used in the different databases. The asterisk represents any group of characters.

\begin{tabular}{|c|c|}
\hline Database & Research \\
\hline Cochrane Library & $\begin{array}{c}\text { \#1 MeSH descriptor: [Dentin] explodes all trees } \\
\text { \#2 dentin } \\
\text { \#3 cavity } \\
\text { \#4 MeSH descriptor: [Disinfection] in all MeSH products } \\
\text { \#5 disinfect* } \\
\text { \#6 antibacteria* } \\
\text { \#7 MeSH descriptor: [Anti-Bacterial Agents] explodes all trees } \\
\text { \#8 chlorhexidine } \\
\text { \#9 MeSH descriptor: [Chlorhexidine] explodes all trees } \\
\text { \#10 “sodium hypochlorite" } \\
\text { \#11 MeSH descriptor: [Sodium Hypochlorite] explodes all trees } \\
\text { \#12 laser } \\
\text { \#13 MeSH descriptor: [Lasers] explodes all trees } \\
\text { \#14 ozone } \\
\text { \#15 MeSH descriptor: [Ozone] explodes all trees } \\
\text { \#16 ethanol } \\
\text { \#17 MeSH descriptor: [Ethanol] explodes all trees } \\
\text { \#18 “aloe vera” } \\
\text { \#19 MeSH descriptor: [Aloe] explodes all trees } \\
\text { \#20 \#1 OR \#2 OR \#3 } \\
\text { \#18 OR \#19 } \\
\text { \#22 adhesion } \\
\text { \#23 adhesive } \\
\text { \#21 \#4 OR \#5 OR \#6 OR \#7 OR \#8 OR \#9 OR \#10 \#11 OR \#13 OR \#12 \#14 OR \#15 OR \#16 OR \#17 OR } \\
\text { \#26 \#22 OR \#23 OR \#24 OR \#25 } \\
\text { \#27 \#20 AND \#21 and \#26 } \\
\text { \#28 \#20 AND \#21 }\end{array}$ \\
\hline Web of Science & $\begin{array}{c}\text { TS = ((dentin[MeSH Terms] OR dentin OR cavity) AND (disinfect* OR antibacteria* OR } \\
\text { chlorhexidine OR "sodium hypochlorite" OR laser OR ozone OR ethanol OR “aloe vera") AND } \\
\text { ("bond strength" OR adhesion or adhesive)) }\end{array}$ \\
\hline Pubmed & $\begin{array}{c}\text { (dentin[MeSH Terms] OR dentin OR cavity) AND (disinfection[MeSH Terms] OR disinfect* OR } \\
\text { antibacteria* OR agents, antibacterial[MeSH Terms] OR chlorhexidine[MeSH Terms] OR } \\
\text { chlorhexidine OR "sodium hypochlorite" OR sodium hypochlorite[MeSH Terms] OR laser OR } \\
\text { lasers[MeSH Terms] OR ozone OR ozone[MeSH Terms] OR ethanol OR ethanol[MeSH Terms] OR } \\
\text { "aloe vera" OR aloe[MeSH Terms]) AND (“bond strength" OR adhesion OR adhesive OR } \\
\text { adhesives[MeSH Terms]) }\end{array}$ \\
\hline
\end{tabular}

\subsection{Quality Assessment of the Included Clinical Studies}

The methodological quality assessment of included clinical studies (randomized controlled trials, RCT) was assessed using the Revised Cochrane risk-of-bias tool for randomized trials (RoB 2) [197] by two independent reviewers. Briefly, five domains were evaluated: (D1) risk of bias arising from the randomization process; (D2) risk of bias due to deviations from the intended interventions; (D3) Risk of bias due to missing outcome data; (D4) Risk of bias in measurement of the outcome; (D5) Risk of bias in selection of the reported results. From this evaluation, each study may vary its overall classification regarding bias risk as "low", "high" or "some concerns". 


\section{Conclusions}

A variety of different products is available for cavity disinfection prior to adhesive procedures. However, there are only a few that have been tested to a proper extent and with proved in vitro and clinical viability.

Chlorhexidine is a popular disinfectant and it was possible to conclude that it is a safe option for cavity disinfection since results are mainly positive with an adequate preservation of adhesion to dentin. Other disinfectants such as EDTA and ethanol may be promising alternatives but there is a clear need for further studies to safely suggest their use as cavity disinfectants. Also, further research is needed to clarify not only the effect of cavity disinfectants in bond strength but also their efficacy against cariogenic bacteria, their application times, products' concentration, their use before or after acid-etching and their combination with different adhesive systems and dental substrates.

Supplementary Materials: Can be found at https:/ /www.mdpi.com/1422-0067/22/1/353/s1.

Author Contributions: Conceptualization, A.C., I.A. and E.C.; methodology, A.C., I.A., A.P., C.M.M., G.S.; software, A.C., I.A.; validation, A.C., I.A., A.P., C.M.M., G.S., M.M.F., E.C.; data extraction and analysis, A.C., I.A., B.R., I.M., J.S., E.C.; writing-original draft preparation, A.C., I.A., B.R., J.S.; writing-review and editing, A.C., I.A., A.P., C.M.M., G.S., M.M.F., E.C.; supervision, A.C., I.A., E.C. All authors have read and agreed to the published version of the manuscript.

Funding: This research received no external funding.

Institutional Review Board Statement: Not applicable.

Informed Consent Statement: Not applicable.

Data Availability Statement: The data presented in this study are available in Supplementary Materials S1 and S2.

Conflicts of Interest: The authors declare no conflict of interest

$\begin{array}{ll}\text { Abbreviations } & \\ \text { CHX } & \text { Chlorhexidine } \\ \text { DT } & \text { Diamond tip } \\ \text { DTUS } & \text { Ultrasonic diamond tip } \\ \text { EDTA } & \text { Ethylenediamine tetraacetic acid } \\ \text { EGCG } & \text { Epillocatechin gallate } \\ \text { MSP } & \text { Medium short pulse } \\ \text { PBS } & \text { Phosphate buffer saline } \\ \text { QSP } & \text { Quantum square pulse } \\ \text { TC } & \text { Thermocyling }\end{array}$

\section{References}

1. Okada, E.M.P.; Ribeiro, L.N.S.; Stuani, M.B.S.; Borsatto, M.C.; Fidalgo, T.K.D.S.; De Paula-Silva, F.W.G.; Küchler, E.C. Effects of chlorhexidine varnish on caries during orthodontic treatment: A systematic review and meta-analysis. Braz. Oral Res. 2016, 30, e115. [CrossRef]

2. Cao, C.Y.; Mei, M.L.; Li, Q.L.; Lo, E.C.M.; Chu, C.H. Methods for biomimetic remineralization of human dentine: A systematic review. Int. J. Mol. Sci. 2015, 16, 4615-4627. [CrossRef]

3. Pinna, R.; Maioli, M.; Eramo, S.; Mura, I.; Milia, E. Carious affected dentine: Its behaviour in adhesive bonding. Aust. Dent. J. 2015, 60, 276-293. [CrossRef] [PubMed]

4. Kidd, E.A.M. How "clean" must a cavity be before restoration? Caries Res. 2004, 38, 305-313. [CrossRef] [PubMed]

5. Demarco, F.F.; Corrêa, M.B.; Cenci, M.S.; Moraes, R.R.; Opdam, N.J.M. Longevity of posterior composite restorations: Not only a matter of materials. Dent. Mater. 2012, 28, 87-101. [CrossRef] [PubMed]

6. Mjör, I.A.; Gordan, V.V. Failure, Repair, Refurbishing and Longevity of Restorations. Oper. Dent. 2002, 27, 528-534. [PubMed]

7. Mjör, I.A.; Moorhead, J.E.; Dahl, J.E.; Haslum, N. Reasons for replacement of restorations in permanent teeth in general dental practice. Int. Dent. J. 2000, 50, 361-366. [CrossRef] [PubMed]

8. Chisini, L.A.; Collares, K.; Cademartori, M.G.; de Oliveira, L.J.C.; Conde, M.C.M.; Demarco, F.F.; Corrêa, M.B. Restorations in primary teeth: A systematic review on survival and reasons for failures. Int. J. Paediatr. Dent. 2018, 28, 123-139. [CrossRef] [PubMed] 
9. De Menezes, L.R.; da Silva, E.O.; Maurat da Rocha, L.V.; Ferreira Barbosa, I.; Rodrigues Tavares, M. The use of clays for chlorhexidine controlled release as a new perspective for longer durability of dentin adhesion. J. Mater. Sci. Mater. Med. 2019, 30, 132. [CrossRef]

10. Bin-Shuwaish, M.S. Effects and effectiveness of cavity disinfectants in operative dentistry: A literature review. J. Contemp. Dent. Pract. 2016, 17, 867-879. [CrossRef]

11. Miranda, C.; Silva, G.V.; Vieira, M.D.; Costa, S.X.S. Influence of the chlorhexidine application on adhesive interface stability: literature review. Rev. Sul-Bras. Odontol. 2014, 11, 276-285.

12. Gwinnett, A.J. Effect of Cavity Disinfection on Bond Strength to Dentin. J. Esthet. Restor. Dent. 1992, 4, 11-13. [CrossRef] [PubMed]

13. Davalloo, R.; Tavangar, M.; Ebrahimi, H.; Darabi, F.; Mahmoudi, S. In Vitro Comparative Evaluation of Newly Produced Desensitizer and Chlorhexidine and Gluma on Bond Strength and Bond Longevity of Composite to Dentin. J. Dent. 2019, 21, 111-118. [CrossRef]

14. Al Deeb, L.; Bin-Shuwaish, M.S.; Abrar, E.; Naseem, M.; Al-Hamdan, R.S.; Maawadh, A.M.; Al Deeb, M.; Almohareb, T.; Al Ahdal, K.; Vohra, F.; et al. Efficacy of chlorhexidine, Er Cr YSGG laser and photodynamic therapy on the adhesive bond integrity of caries affected dentin. An in-vitro study. Photodiagnosis Photodyn. Ther. 2020, 31, 101875. [CrossRef]

15. Mapar, M.; Moalemnia, M.; Kalantari, S. Comparison of the effect of Chlorhexidine and collagen cross-linking agent (Quercus Extract) on the tensile bond strength of composite to dentin. Med. Sci. 2020, 24, 1168-1175.

16. Fernandes, G.L.; Strazzi-Sahyon, H.B.; Suzuki, T.Y.U.; Briso, A.L.F.; dos Santos, P.H. Influence of chlorhexidine gluconate on the immediate bond strength of a universal adhesive system on dentine subjected to different bonding protocols: An in vitro pilot study. Oral Heal. Prev. Dent. 2020, 18, 71-76. [CrossRef]

17. Geng Vivanco, R.; Cardoso, R.S.; Sousa, A.B.S.; Chinelatti, M.A.; de Vincenti, S.A.F.; Tonani-Torrieri, R.; Pires-de-Souza, F. de C.P. Effect of thermo-mechanical cycling and chlorhexidine on the bond strength of universal adhesive system to dentin. Heliyon 2020, 6, e03871. [CrossRef]

18. Nima, G.; Cavalli, V.; Bacelar-Sá, R.; Ambrosano, G.M.B.; Giannini, M. Effects of sodium hypochlorite as dentin deproteinizing agent and aging media on bond strength of two conventional adhesives. Microsc. Res. Tech. 2020, 83, 186-195. [CrossRef]

19. Yazici, E.; Gurgan, S.; Gutknecht, N.; Imazato, S. Effects of erbium: Yttrium-aluminum-garnet and neodymium: Yttriumaluminum-garnet laser hypersensitivity treatment parameters on the bond strength of self-etch adhesives. Lasers Med. Sci. 2010, 25, 511-516. [CrossRef]

20. Koshiro, K.; Inoue, S.; Niimi, K.; Koase, K.; Sano, H. Bond strength and SEM observation of CO2 laser irradiated dentin, bonded with simplified-step adhesives. Oper. Dent. 2005, 30, 170-179.

21. Rolla, J.N.; Mota, E.G.; Oshima, H.M.S.; Burnett, L.H.; Spohr, A.M. Nd:YAG laser influence on microtensile bond strength of different adhesive systems for human dentin. Photomed. Laser Surg. 2006, 24, 730-734. [CrossRef] [PubMed]

22. Gan, J.; Liu, S.; Zhou, L.; Wang, Y.; Guo, J.; Huang, C. Effect of Nd:YAG laser irradiation pretreatment on the long-term bond strength of etch-and-rinse adhesive to dentin. Oper. Dent. 2016, 42, 62-72. [CrossRef] [PubMed]

23. Erhardt, M.C.G.; Osorio, R.; Toledano, M. Dentin treatment with MMPs inhibitors does not alter bond strengths to caries-affected dentin. J. Dent. 2008, 36, 1068-1073. [CrossRef] [PubMed]

24. Mobarak, E.H. Effect of chlorhexidine pretreatment on bond strength durability of caries-affected dentin over 2-year aging in artificial saliva and under simulated intrapulpal pressure. Oper. Dent. 2011, 36, 649-660. [CrossRef] [PubMed]

25. Kunawarote, S.; Nakajima, M.; Foxton, R.M.M.; Tagami, J. Effect of pretreatment with mildly acidic hypochlorous acid on adhesion to caries-affected dentin using a self-etch adhesive. Eur. J. Oral Sci. 2011, 119, 86-92. [CrossRef]

26. Ozsoy, A.; Erdemir, U.; Yucel, T.; Yildiz, E. Effects of cavity disinfectants on bond strength of an etch-and-rinse adhesive to wateror ethanol-saturated sound and caries-affected dentin. J. Adhes. Sci. Technol. 2015, 29, 2551-2564. [CrossRef]

27. Lenzi, T.L.; Tedesco, T.K.; Soares, F.Z.M.; Loguercio, A.D.; de O Rocha, R. Chlorhexidine does not increase immediate bond strength of etch-and-rinse adhesive to caries-affected dentin of primary and permanent teeth. Braz. Dent. J. 2012, 23, 438-442. [CrossRef]

28. Kucukyilmaz, E.; Savas, S.; Akcay, M.; Bolukbasi, B. Effect of silver diamine fluoride and ammonium hexafluorosilicate applications with and without Er:YAG laser irradiation on the microtensile bond strength in sound and caries-affected dentin. Lasers Surg. Med. 2016, 48, 62-69. [CrossRef]

29. Cersosimo, M.C.P.; Matos, A.B.; Couto, R.S.D.; Marques, M.M.; de Freitas, P.M. Short-pulse Er:YAG laser increases bond strength of composite resin to sound and eroded dentin. J. Biomed. Opt. 2016, 21, 48001. [CrossRef]

30. Toledano, M.; Perdigão, J.; Osorio, E.; Osorio, R. Influence of NaOCl deproteinization on shear bond strength in function of dentin depth. Am. J. Dent. 2002, 15, 252-255.

31. Ceballos, L.; Toledano, M.; Osorio, R. Bonding to Er-YAG-laser- treated Dentin. J. Dent. Res. 2002, 81, 119-122. [CrossRef]

32. Uceda-Gómez, N.; Reis, A.; Carrilho, M.R.D.O.; Loguercio, A.D.; Rodriguez Filho, L.E. Effect of sodium hypochlorite on the bond strength of an adhesive system to superficial and deep dentin. J. Appl. Oral Sci. 2003, 11, 223-228. [CrossRef] [PubMed]

33. Gonçalves, M.; Corona, S.A.M.; Palma-Dibb, R.G.; Pécora, J.D. Influence of pulse repetition rate of Er:YAG laser and dentin depth on tensile bond strength of dentin-resin interface. J. Biomed. Mater. Res. Part A 2007, 86, 477-482. [CrossRef] [PubMed]

34. Aguilera, F.S.; Osorio, R.; Osorio, E.; Moura, P.; Toledano, M. Bonding efficacy of an acetone/based etch-and-rinse adhesive after dentin deproteinization. Med. Oral Patol. Oral Cir. Bucal 2012, 17, 649-654. [CrossRef] 
35. Montagner, A.F.; Skupien, J.A.; Borges, M.F.; Krejci, I.; Bortolotto, T.; Susin, A.H. Effect of sodium hypochlorite as dentinal pretreatment on bonding strength of adhesive systems. Indian J. Dent. Res. 2015, 26, 416-420. [CrossRef]

36. Bueno, M.D.F.T.; Basting, R.T.; Turssi, C.P.; França, F.M.G.; Amaral, F.L.B. Effect of $2 \%$ chlorhexidine digluconate application and water storage on the bond strength to superficial and deep dentin. J. Adhes. Sci. Technol. 2015, 29, 1258-1267. [CrossRef]

37. Alaghehmand, H.; Nasrollah, F.N.; Nokhbatolfoghahaei, H.; Fekrazad, R. An in vitro comparison of the bond strength of composite to superficial and deep dentin, treated with Er:YAG laser irradiation or acid-etching. J. Lasers Med. Sci. 2016, 7, 167-171. [CrossRef]

38. Karadas, M.; Çağlar, İ. The effect of Er:YAG laser irradiation on the bond stability of self-etch adhesives at different dentin depths. Lasers Med. Sci. 2017, 32, 967-974. [CrossRef]

39. Say, E.C.; Koray, F.; Tarim, B.; Soyman, M.; Gülmez, T. In vitro effect of cavity disinfectants on the bond strength of dentin bonding systems. Quintessence Int. 2004, 35, 56-60.

40. Franke, M.; Taylor, A.W.; Lago, A.; Fredel, M.C. Influence of Nd:YAG laser irradiation on an adhesive restorative procedure. Oper. Dent. 2006, 31, 604-609. [CrossRef]

41. Malta, D.A.M.P.; Kreidler, M.A.M.; Villa, G.E.; De Andrade, M.F.; Fontana, C.R.; Lizarelli, R.F.Z. Bond strength of adhesive restorations to Er: YAG laser-treated dentin. Laser Phys. Lett. 2007, 4, 153-156. [CrossRef]

42. Campos, E.A.; Correr, G.M.; Leonardi, D.P.; Barato-Filho, F.; Gonzaga, C.C.; Zielak, J.C. Chlorhexidine diminishes the loss of bond strength over time under simulated pulpal pressure and thermo-mechanical stressing. J. Dent. 2009, 37, 108-114. [CrossRef] [PubMed]

43. Sierpinsky, L.M.G.; Lima, D.M.; Candido, M.S.M.; Bagnato, V.S.; Porto-Neto, S.T. Microtensile bond strength of different adhesive systems in dentin irradiated with Er:YAG laser. Laser Phys. Lett. 2008, 5, 547-551. [CrossRef]

44. Yazici, A.R.; Karaman, E.; Ertan, A.; Özgünaltay, G.; Dayangaç, B. Effect of different pretreatment methods on dentin bond strength of a one-step self-etch adhesive. J. Contemp. Dent. Pract. 2009, 10, 41-48. [CrossRef] [PubMed]

45. Baseggio, W.; Consolmagno, E.C.; De Carvalho, F.L.N.; Ueda, J.K.; Schmitt, V.L.; Formighieri, L.A.; Naufel, F.S. Effect of deproteinization and tubular occlusion on microtensile bond strength and marginal microleakage of resin composite restorations. J. Appl. Oral Sci. 2009, 17, 462-466. [CrossRef] [PubMed]

46. Eugénio, S.; Osorio, R.; Sivakumar, M.; Vilar, R.; Monticelli, F.; Toledano, M. Bond Strength of an Etch-and-Rinse Adhesive to KrF Excimer Laser-Treated Dentin. Photomed. Laser Surg. 2010, 28, 97-102. [CrossRef]

47. Kunawarote, S.; Nakajima, M.; Shida, K.; Kitasako, Y.; Foxton, R.M.M.; Tagami, J. Effect of dentin pretreatment with mild acidic $\mathrm{HOCl}$ solution on microtensile bond strength and surface pH. J. Dent. 2010, 38, 261-268. [CrossRef]

48. Rodrigues, P.C.F.C.F.; Souza, J.B.B.; Soares, C.J.J.; Lopes, L.G.G.; Estrela, C. Effect of ozone application on the resindentin microtensile bond strength. Oper. Dent. 2011, 36, 537-544. [CrossRef]

49. Nguyen, D.; Chang, K.; Hedayatollahnajafi, S.; Staninec, M.; Chan, K.; Lee, R.; Fried, D. High-speed scanning ablation of dental hard tissues with a $\lambda=9.3 \mu \mathrm{m} \mathrm{CO}$ laser: Adhesion, mechanical strength, heat accumulation, and peripheral thermal damage. J. Biomed. Opt. 2011, 16, 71410. [CrossRef]

50. Carvalho, A.O.; Reis, A.F.; De Oliveira, M.T.; De Freitas, P.M.; Aranha, A.C.C.; Eduardo, C.D.P.; Giannini, M. Bond strength of adhesive systems to Er,Cr: YSGG laser-irradiated dentin. Photomed. Laser Surg. 2011, 29, 747-752. [CrossRef]

51. De Castro, F.L.A.; Andrade, M.F.; Hebling, J.; Lizarelli, R.F.Z. Nd: YAG laser irradiation of etched/unetched dentin through an uncured two-step etch-and-rinse adhesive and its effect on microtensile bond strength. J. Adhes. Dent. 2012, 14, 137-145. [CrossRef]

52. Gerhardt-Szep, S.; Werelius, K.; De Weerth, F.; Heidemann, D.; Weigl, P. Influence of femtosecond laser treatment on shear bond strength of composite resin bonding to human dentin under simulated pulpal pressure. J. Biomed. Mater. Res. Part B Appl. Biomater. 2012, 100, 177-184. [CrossRef]

53. Verma, R.; Singh, U.P.; Tyagi, S.P.; Nagpal, R.; Manuja, N. Long-term bonding effectiveness of simplified etch-and-rinse adhesives to dentin after different surface pre-treatments. J. Conserv. Dent. 2013, 16, 367-370. [PubMed]

54. De Oliveira, M.T.; Reis, A.F.; Arrais, C.A.G.; Cavalcanti, A.N.; Aranha, A.C.C.; De Paula Eduardo, C.; Giannini, M. Analysis of the interfacial micromorphology and bond strength of adhesive systems to Er:YAG laser-irradiated dentin. Lasers Med. Sci. 2013, 28, 1069-1076. [CrossRef] [PubMed]

55. Bridi, E.C.; Amaral, F.L.B.; Turssi, C.P.; Basting, R.T. Influence of dentin pretreatment with titanium tetrafluoride and self-etching adhesive systems on microtensile bond strength. Am. J. Dent. 2013, 26, 121-126. [PubMed]

56. Santiago, S.L.; Osorio, R.; Neri, J.R.; De Carvalho, R.M.; Toledano, M. Effect of the flavonoid epigallocatechin-3-gallate on resin-dentin bond strength. J. Adhes. Dent. 2013, 15, 535-540. [CrossRef]

57. Zheng, P.; Zaruba, M.; Attin, T.; Wiegand, A. Effect of different matrix metalloproteinase inhibitors on microtensile bond strength of an etch-and-rinse and a self-etching adhesive to dentin. Oper. Dent. 2014, 40, 80-86. [CrossRef]

58. Shirani, F.; Birang, R.; Malekipour, M.R.; Hourmehr, Z.; Kazemi, S. Shear bond strength of resin composite bonded with two adhesives: Influence of Er: YAG laser irradiation distance. Dent. Res. J. (Isfahan) 2014, 11, 689-694.

59. Manso, A.P.; Grande, R.H.M.; Bedran-Russo, A.K.; Reis, A.; Loguercio, A.D.; Pashley, D.H.; Carvalho, R.M. Can 1\% chlorhexidine diacetate and ethanol stabilize resin-dentin bonds? Dent. Mater. 2014, 30, 735-741. [CrossRef]

60. Castro, F.L.A.; Carvalho, J.G.; Andrade, M.F.; Saad, J.R.C.; Hebling, J.; Lizarelli, R.F.Z. Bond strength of composite to dentin: Effect of acid etching and laser irradiation through an uncured self-etch adhesive system. Laser Phys. 2014, 24, 1. [CrossRef] 
61. Simões, D.M.S.; Basting, R.T.; Amaral, F.L.B.; Turssi, C.P.; França, F.M.G. Influence of chlorhexidine and/or ethanol treatment on bond strength of an etch-and-rinse adhesive to dentin: An in vitro and in situ study. Oper. Dent. 2014, 39, 64-71. [CrossRef] [PubMed]

62. Galafassi, D.; Scatena, C.; Colucci, V.; Rodrigues, A.L.; Campos Serra, M.; Milori Corona, S.A. Long-term chlorhexidine effect on bond strength to Er: YAG laser irradiated-dentin. Microsc. Res. Tech. 2014, 77, 37-43. [CrossRef] [PubMed]

63. Maenosono, R.M.A.; Bim Júnior, O.; Duarte, M.A.N.H.; Palma-Dibb, R.G.U.; Wang, L.; Ishikiriama, S.K. Diode laser irradiation increases microtensile bond strength of dentin. Braz. Oral Res. 2015, 29, 1-5. [CrossRef] [PubMed]

64. Chauhan, K.; Basavanna, R.S.; Shivanna, V. Effect of bromelain enzyme for dentin deproteinization on bond strength of adhesive system. J. Conserv. Dent. 2015, 18, 360-363. [CrossRef] [PubMed]

65. Sinha, D.J.; Jaiswal, N.; Vasudeva, A.; Garg, P.; Tyagi, S.P.; Chandra, P. Comparative Evaluation of the Effect of Chlorhexidine and Aloe Barbadensis Miller (Aloe Vera) on Dentin Stabilization Using Shear Bond Testing. J Conserv Dent 2016, 19, 406-409. [CrossRef]

66. Cha, H.S.; Shin, D.H. Antibacterial capacity of cavity disinfectants against Streptococcus mutans and their effects on shear bond strength of a self-etch adhesive. Dent. Mater. J. 2016, 35, 147-152. [CrossRef]

67. Gerhardt, K.M.F.; Oliveira, C.A.R.; França, F.M.G.; Basting, R.T.; Turssi, C.P.; Amaral, F.L.B. Effect of epigallocatechin gallate, green tea extract and chlorhexidine application on long-term bond strength of self-etch adhesive to dentin. Int. J. Adhes. Adhes. 2016, 71, 23-27. [CrossRef]

68. Balloni, E.C.P.; Do Amaral, F.L.B.; França, F.M.G.; Turssi, C.P.; Basting, R.T. Influence of chlorhexidine in cavities prepared with ultrasonic or diamond tips on microtensile bond strength. J. Adhes. Sci. Technol. 2016, 31, 1133-1141. [CrossRef]

69. Neri, J.R.; de Nojosa, J.S.; Yamauti, M.; Mendonça, J.S.; Santiago, S.L. Pretreatment with sodium fluoride maintains dentin bond strength of a two-step self-etch adhesive after thermal stressing. J. Adhes. Dent. 2017, 19, 517-523. [CrossRef]

70. Kim, B.R.; Oh, M.H.; Shin, D.H. Effect of cavity disinfectants on antibacterial activity and microtensile bond strength in class I cavity. Dent. Mater. J. 2017, 36, 368-373. [CrossRef]

71. Rechmann, P.; Bartolome, N.; Kinsel, R.; Vaderhobli, R.; Rechmann, B.M.T. Bond strength of etch-and-rinse and self-etch adhesive systems to enamel and dentin irradiated with a novel CO2 $9.3 \mu \mathrm{m}$ short-pulsed laser for dental restorative procedures. Lasers Med. Sci. 2017, 32, 1981-1993. [CrossRef] [PubMed]

72. Alaghehmad, H.; Mansouri, E.; Esmaili, B.; Bijani, A.; Nejadkarimi, S.; Rahchamani, M. Effect of 0.12\% chlorhexidine and zinc nanoparticles on the microshear bond strength of dentin with a fifth-generation adhesive. Eur. J. Dent. 2018, 12, 105-110. [CrossRef] [PubMed]

73. Jowkar, Z.; Shafiei, F.; Asadmanesh, E.; Koohpeima, F. Influence of silver nanoparticles on resin-dentin bond strength durability in a self-etch and an etch-and-rinse adhesive system. Restor. Dent. Endod. 2019, 44, 1-9. [CrossRef] [PubMed]

74. Sharafeddin, F.; Haghbin, N. Comparison of Bromelain Enzyme, Sodium Hypochlorite, and Titanium Tetrafluoride on Shear Bond Strength of Restorative Composite to Dentin: An in vitro Study. J. Dent. (Shiraz Iran) 2019, 20, 264-270. [CrossRef]

75. Hussein, A.A.A.; Al-Shamma, A.M.W. Effect of Chlorhexidine and/or Ethanol Pre-bonding Treatment on the Shear Bond Strength of Resin Composite to Dentin. Int. J. Med. Res. Heal. Sci. 2019, 8, 150-159.

76. Kasraei, S.; Yarmohamadi, E.; Ranjbaran Jahromi, P.; Akbarzadeh, M. Effect of 940nm Diode Laser Irradiation on Microtensile Bond Strength of an Etch and Rinse Adhesive (Single Bond 2) to Dentin. J. Dent. (Shiraz Iran) 2019, 20, 30-36. [CrossRef]

77. Perdigao, J.; Denehy, G.E.; Swift, E.J. Effects of chlorhexidine on dentin surfaces and shear bond strengths. Am. J. Dent. 1994, 7,81-84.

78. Ramos, R.P.; Chimello, D.T.; Chinelatti, M.A.; Nonaka, T.; Pécora, J.D.; Palma Dibb, R.G. Effect of Er:YAG laser on bond strength to dentin of a self-etching primer and two single-bottle adhesive systems. Lasers Surg. Med. 2002, 31, 164-170. [CrossRef]

79. De Castro, F.L.A.; De Andrade, M.F.; Duarte Júnior, S.L.L.; Vaz, L.G.; Ahid, F.J.M. Effect of $2 \%$ chlorhexidine on microtensile bond strength of composite to dentin. J. Adhes. Dent. 2003, 5, 129-138. [CrossRef]

80. Visuri, S.R.; Gilbert, J.L.; Wright, D.D.; Wigdor, H.A.; Walsh, J.T.J. Shear strength of composite bonded to Er: YAG laser-prepared dentin. J. Dent. Res. 1996, 75, 599-605. [CrossRef]

81. Gürgan, S.; Bolay, Ş.; Kiremitçi, A. Effect of disinfectant application methods on the bond strength of composite to dentin. J. Oral Rehabil. 1999, 26, 836-840. [CrossRef] [PubMed]

82. Gonçalves, M.; Milori Corona, S.A.; Borsatto, M.C.; Gomes Silva, P.C.; Djalma Pécora, J. Tensile bond strength of dentin-resinous system interfaces conditioned with Er:YAG laser irradiation. J. Clin. Laser Med. Surg. 2002, 20, 89-93. [CrossRef]

83. Dunn, W.J.; Davis, J.T.; Bush, A.C. Shear bond strength and SEM evaluation of composite bonded to Er:YAG laser-prepared dentin and enamel. Dent. Mater. 2005, 21, 616-624. [CrossRef]

84. Osorio, R.; Erhardt, M.C.G.; Pimenta, L.A.F.; Osorio, E.; Toledano, M. EDTA treatment improves resin-dentin bonds' resistance to degradation. J. Dent. Res. 2005, 84, 736-740. [CrossRef] [PubMed]

85. Abo, T.; Asmussen, E.; Uno, S.; Tagami, J. Short- and long-term in vitro study of the bonding of eight commercial adhesives to normal and deproteinized dentin. Acta Odontol. Scand. 2006, 64, 237-243. [CrossRef] [PubMed]

86. Loguercio, A.D.; Stanislawczuk, R.; Polli, L.G.; Costa, J.A.; Michel, M.D.; Reis, A. Influence of chlorhexidine digluconate concentration and application time on resin-dentin bond strength durability. Eur. J. Oral Sci. 2009, 117, 587-596. [CrossRef]

87. Stanislawczuk, R.; Amaral, R.C.; Zander-Grande, C.; Gagler, D.; Reis, A.; Loguercio, A.D. Chlorhexidine-containing acid conditioner preserves the longevity of resin-dentin bonds. Oper. Dent. 2009, 34, 481-490. [CrossRef] 
88. Çelik, Ç.; Özel, Y.; Bağiş, B.; Erkut, S. Effect of laser irradiation and cavity disinfectant application on the microtensile bond strength of different adhesive systems. Photomed. Laser Surg. 2010, 28, 267-272. [CrossRef]

89. Ferreira, L.S.; Apel, C.; Francci, C.; Simoes, A.; Eduardo, C.P.; Gutknecht, N. Influence of etching time on bond strength in dentin irradiated with erbium lasers. Lasers Med. Sci. 2010, 25, 849-854. [CrossRef]

90. Mohammad, E.E.C.; Amir, A.; Soodabeh, K.; Ahmad, A. Effect of chlorhexidine on the shear bond strength of self-etch adhesives to dentin. African J. Biotechnol. 2011, 10, 10054-10057. [CrossRef]

91. Stanislawczuk, R.; Reis, A.; Loguercio, A.D. A 2-year in vitro evaluation of a chlorhexidine-containing acid on the durability of resin-dentin interfaces. J. Dent. 2011, 39, 40-47. [CrossRef] [PubMed]

92. Mohammad, E.E.C.; Mehdi, A.K.; Soodabeh, K.; Mohammadreza, H.M. Effect of sodium hypochlorite on the shear bond strength of fifth- and seventh-generation adhesives to coronal dentin. African J. Biotechnol. 2011, 10, 12697-12701. [CrossRef]

93. Garcia, E.J.; Serrano, A.P.M.; Urruchi, W.I.; Deboni, M.C.; Reis, A.; Grande, R.H.M.; Loguercio, A.D. Influence of ozone gas and ozonated water application to dentin and bonded interfaces on resin-dentin bond strength. J. Adhes. Dent. 2012, 14, 363-370. [CrossRef]

94. Firat, E.; Gurgan, S.; Gutknecht, N. Microtensile bond strength of an etch-and-rinse adhesive to enamel and dentin after Er:YAG laser pretreatment with different pulse durations. Lasers Med. Sci. 2012, 27, 15-21. [CrossRef] [PubMed]

95. Baraba, A.; Dukić, W.; Chieffi, N.; Ferrari, M.; Anić, I.; Miletić, I. Influence of different pulse durations of Er:YAG Laser based on variable square pulse technology on microtensile bond strength of a self-etch adhesive to dentin. Photomed. Laser Surg. 2013, 31, 116-124. [CrossRef]

96. Ustunkol, I.; Yazici, A.R.; Gorucu, J.; Dayangac, B. Influence of laser etching on enamel and dentin bond strength of Silorane System Adhesive. Lasers Med. Sci. 2015, 30, 695-700. [CrossRef]

97. Zhou, L.; Wang, Y.; Yang, H.; Guo, J.; Tay, F.R.; Huang, C. Effect of chemical interaction on the bonding strengths of self-etching adhesives to deproteinised dentine. J. Dent. 2015, 43, 973-980. [CrossRef]

98. Da Silva, E.M.; Glir, D.H.; Gill, A.W.M.C.; Giovanini, A.F.; Furuse, A.Y.; Gonzaga, C.C. Effect of chlorhexidine on dentin bond strength of two adhesive systems after storage in different media. Braz. Dent. J. 2015, 26, 642-647. [CrossRef]

99. Koizumi, H.; Hamama, H.H.; Burrow, M.F. Effect of a silver diamine fluoride and potassium iodide-based desensitizing and cavity cleaning agent on bond strength to dentine. Int. J. Adhes. Adhes. 2016, 68, 54-61. [CrossRef]

100. Tekçe, N.; Tuncer, S.; Demirci, M.; Balci, S. Do matrix metalloproteinase inhibitors improve the bond durability of universal dental adhesives? Scanning 2016, 38, 535-544. [CrossRef]

101. Ruschel, V.C.; Malta, D.A.M.P.; Monteiro, S. Dentin bond strength of an adhesive system irradiated with an Nd:YAG laser. Laser Phys. 2016, 26, 116101. [CrossRef]

102. Kusdemir, M.; Çetin, A.R.; Özsoy, A.; Toz, T.; Öztürk Bozkurt, F.; Özcan, M. Does 2\% chlorhexidine digluconate cavity disinfectant or sodium fluoride/hydroxyethyl methacrylate affect adhesion of universal adhesive to dentin? J. Adhes. Sci. Technol. 2016, 30, 13-23. [CrossRef]

103. Oliveira, H.; Tedesco, T.K.; Rodrigues-Filho, L.E.; Soares, F.Z.M.; Rocha, O.R. Doxycycline as a matrix metalloproteinase inhibitor to prevent bond degradation: The effect of acid and neutral solutions on dentin bond strength. Gen. Dent. 2016, 64, 14-17.

104. Loguercio, A.D.; Stanislawczuk, R.; Malaquias, P.; Gutierrez, M.F.; Bauer, J.; Reis, A. Effect of minocycline on the durability of dentin bonding produced with etch-and- rinse adhesives. Oper. Dent. 2016, 41, 511-519. [CrossRef]

105. Loguercio, A.D.; Hass, V.; Gutierrez, M.F.; Luque-Martinez, I.V.; Szezs, A.; Stanislawczuk, R.; Bandeca, M.C.; Reis, A. Five-year effects of chlorhexidine on the in vitro durability of resin/dentin interfaces. J. Adhes. Dent. 2016, 18, 35-42. [CrossRef]

106. Sharafeddin, F.; Koohpeima, F.; Razazan, N. The Effect of Titanium Tetrafluoride and Sodium Hypochlorite on the Shear Bond Strength of Methacrylate and Silorane Based Composite Resins: An In-Vitro Study. J. Dent. (Shiraz Iran) 2017, $18,82-87$.

107. Kucukyilmaz, E.; Botsali, M.S.; Korkut, E.; Sener, Y.; Sari, T. Effect of Different Modes of Erbium:yttrium Aluminum Garnet Laser on Shear Bond Strength To Dentin. Niger. J. Clin. Pract. 2017, 20, 1277-1282.

108. Jowkar, Z.; Farpour, N.; Koohpeima, F.; Mokhtari, M.J.; Shafiei, F. Effect of silver nanoparticles, zinc oxide nanoparticles and titanium dioxide nanoparticles on microshear bond strength to enamel and dentin. J. Contemp. Dent. Pract. 2018, 19, 1405-1412. [CrossRef]

109. Silva, A.C.; Melo, P.; Ferreira, J.; Oliveira, S.; Gutknecht, N. Influence of grape seed extract in adhesion on dentin surfaces conditioned with Er,Cr:YSGG laser. Lasers Med. Sci. 2019, 34, 1493-1501. [CrossRef]

110. Wang, J.; Song, W.; Zhu, L.; Wei, X. A comparative study of the microtensile bond strength and microstructural differences between sclerotic and Normal dentine after surface pretreatment. BMC Oral Health 2019, 19, 216. [CrossRef]

111. Breschi, L.; Cammelli, F.; Visintini, E.; Mazzoni, A.; Carrilho, M.; Cadenaro, M.; Foulger, S.; Tay, F.R. Influence of chlorhexidine concentration on the durability of etch-and-rinse dentin bonds: A 12-month in vitro study. J. Adhes. Dent. 2009, 11, 191-198. [PubMed]

112. Ramos, A.C.B.; Esteves-Oliveira, M.; Arana-Chavez, V.E.; De Paula Eduardo, C. Adhesives bonded to erbium: Yttrium-aluminumgarnet laser-irradiated dentin: Transmission electron microscopy, scanning electron microscopy and tensile bond strength analyses. Lasers Med. Sci. 2010, 25, 181-189. [CrossRef] [PubMed]

113. Dalli, M.; Ercan, E.; Zorba, Y.O.; Ince, B.; Şahbaz, C.; Bahşi, E.; Çolak, H. Effect of 1\% chlorhexidine gel on the bonding strength to dentin. J. Dent. Sci. 2010, 5, 8-13. [CrossRef] 
114. Sano, K.; Tonami, K.I.; Ichinose, S.; Araki, K. Effects of ArF excimer laser irradiation of dentin on the tensile bonding strength to composite resin. Photomed. Laser Surg. 2012, 30, 71-76. [CrossRef] [PubMed]

115. Saraceni, C.H.; Liberti, E.; Navarro, R.S.; Cassoni, A.; Kodama, R.; Oda, M. Er:YAG-laser and sodium hypochlorite influence on bond to dentin. Microsc. Res. Tech. 2013, 76, 72-78. [CrossRef]

116. Jiang, Q.; Chen, M.; Ding, J. Comparison of tensile bond strengths of four one-bottle self-etching adhesive systems with Er:YAG laser-irradiated dentin. Mol. Biol. Rep. 2013, 40, 7053-7059. [CrossRef]

117. Ribeiro, C.F.; de Paiva Gonçalves, S.E.; Yui, K.C.K.; Borges, A.B.; Barcellos, D.C.; Brayner, R. Dentin Bond Strength: Influence of Er:YAG and Nd:YAG Lasers. Int. J. Periodontics Restor. Dent. 2013, 33, 373-377. [CrossRef]

118. Kasraei, S.; Azarsina, M.; Khamverdi, Z. Effect of Ethylene diamine tetra acetic acid and sodium hypochlorite solution conditioning on microtensile bond strength of one-step self-etch adhesives. J. Conserv. Dent. 2013, 16, 243-246. [CrossRef]

119. Portillo, M.; Lorenzo, M.C.; Moreno, P.; García, A.; Montero, J.; Ceballos, L.; Fuentes, M.V.; Albaladejo, A. Influence of Er:YAG and Ti:sapphire laser irradiation on the microtensile bond strength of several adhesives to dentin. Lasers Med. Sci. 2015, 30, 483-492. [CrossRef]

120. Heredia, A.; Ferreira da Silva, D.F.; Gluer Carracho, H.; Borges, G.A.; Spohr, A.M. Influence of Nd:YAG laser on the durability of resin-dentin bonds. J. Laser Appl. 2015, 27, 42004. [CrossRef]

121. Pucci, C.R.; Barbosa, N.R.; Bresciani, E.; Yui, K.C.K.; Filomena, M.R.L.H.; Barcellos, D.C.; Torres, C.R.G. Influence of dentin deproteinization on bonding degradation: 1-year results. J. Contemp. Dent. Pract. 2016, 17, 985-989. [CrossRef] [PubMed]

122. Gunaydin, Z.; Yazici, A.R.; Cehreli, Z.C. In vivo and in vitro effects of chlorhexidine pretreatment on immediate and aged dentin bond strengths. Oper. Dent. 2016, 41, 258-267. [CrossRef] [PubMed]

123. Bravo, C.; Sampaio, C.S.S.; Hirata, R.; Puppin-Rontani, R.M.M.; Mayoral, J.R.R.; Giner, L. In-vitro Comparative Study of the use of $2 \%$ Chlorhexidine on Microtensile Bond Strength of Different Dentin Adhesives: A 6 Months Evaluation. Int. J. Morphol. 2017, 35, 893-900. [CrossRef]

124. Bravo, C.; Sampaio, C.S.; Hirata, R.; Puppin-Rontani, R.M.; Mayoral, J.R.; Giner, L. Effect of 2 \% Chlorhexidine on Dentin Shear Bond Strength of Different Adhesive Systems: A 6 Months Evaluation. Int. J. Morphol. 2017, 35, 1140-1146. [CrossRef]

125. Trevelin, L.T.; Da Silva, B.T.F.; De Freitas, P.M.; Matos, A.B. Influence of Er:YAG laser pulse duration on the long-term stability of organic matrix and resin-dentin interface. Lasers Med. Sci. 2019, 34, 1391-1399. [CrossRef]

126. El-housseiny, A.A.; Jamjoum, H. The effect of caries detector dyes and a cavity cleanising agent on Composite Resin Bonding To Enamel and Dentin. J. Clin. Pediatric Dent. 2000, 25, 57-64. [CrossRef]

127. Da Silva, N.R.F.A.; Calamia, C.S.; Coelho, P.G.; Carrilho, M.R.D.O.; De Carvalho, R.M.; Caufield, P.; Thompson, P. Van Effect of $2 \%$ iodine disinfecting solution on bond strength to dentin. J. Appl. Oral Sci. 2006, 14, 399-404. [CrossRef]

128. Bengtson, C.R.G.; Bengtson, A.L.; Bengtson, N.G.; Turbino, M.L. Efeito da Clorexidina 2\% na Resistência de União de Dois Sistemas Adesivos à Dentina Humana. Pesq. Bras. Odontoped Clin. Integr. 2008, 8, 51-56. [CrossRef]

129. Fawzy, A.S.; Amer, M.A.; El-Askary, F.S. Sodium hypochlorite as dentin pretreatment for etch-and-rinse single-bottle and two-step self-etching adhesives: Atomic force microscope and tensile bond strength evaluation. J. Adhes. Dent. 2008, 10, 135-144. [CrossRef]

130. Sauro, S.; Mannocci, F.; Toledano, M.; Osorio, R.; Pashley, D.H.; Watson, T.F. EDTA or H3PO4/NaOCl dentine treatments may increase hybrid layers' resistance to degradation: A microtensile bond strength and confocal-micropermeability study. J. Dent. 2009, 37, 279-288. [CrossRef]

131. Chou, J.C.; Chen, C.C.; Ding, S.J. Effect of Er,Cr:YSGG laser parameters on shear bond strength and microstructure of dentine. Photomed. Laser Surg. 2009, 27, 481-486. [CrossRef] [PubMed]

132. Elkassas, D.W.; Fawzi, E.M.; El Zohairy, A. The effect of cavity disinfectants on the micro-shear bond strength of dentin adhesives. Eur. J. Dent. 2014, 8, 184-190. [CrossRef] [PubMed]

133. Ercan, E.; Çolak, H.; Hamidi, M.M.; İbrahimov, D.; Gulal, E. Can Dentin Surfaces Be Bonded Safely With Ozone and Boric Acid? Ozone Sci. Eng. 2015, 37, 556-562. [CrossRef]

134. Sinha, D.J.; Jandial, U.A.; Jaiswal, N.; Singh, U.P.; Goel, S.; Singh, O. Comparative evaluation of the effect of different disinfecting agents on bond strength of composite resin to dentin using two-step self-etch and etch and rinse bonding systems: An in-vitro study. J. Conserv. Dent. 2018, 21, 424-427. [CrossRef] [PubMed]

135. Sacramento, P.A.; De Castilho, A.R.F.; Banzi, É.C.F.; Puppi-Rontani, R.M. Influence of cavity disinfectant and adhesive systems on the bonding procedure in demineralized dentin-a one-year in vitro evaluation. J. Adhes. Dent. 2012, 14, 575-583. [CrossRef] [PubMed]

136. Sun, Q.; Gu, L.; Quan, J.; Yu, X.; Huang, Z.; Wang, R.; Mai, S. Epigallocatechin-3-gallate enhance dentin biomodification and bond stability of an etch-and-rinse adhesive system. Int. J. Adhes. Adhes. 2018, 80, 115-121. [CrossRef]

137. Kalaiselvam, R.; Ganesh, A.; Rajan, M.; Kandaswamy, D. Evaluation of bioflavonoids on the immediate and delayed microtensile bond strength of self-etch and total-etch adhesive systems to sound dentin. Indian J. Dent. Res. 2018, 29, 133-136. [CrossRef]

138. Prati, C.; Chersoni, S.; Pashley, D.H. Effect of removal of surface collagen fibrils on resin-dentin bonding. Dent. Mater. 1999, 15, 323-331. [CrossRef]

139. Huang, M.S.; Li, M.T.; Huang, F.M.; Ding, S.J. The effect of thermocycling and dentine pre-treatment on the durability of the bond between composite resin and dentine. J. Oral Rehabil. 2004, 31, 492-499. [CrossRef] 
140. Ramos, R.P.; Chinelatti, M.A.; Chimello, D.T.; Borsatto, M.C.; Pécora, J.D.; Palma-Dibb, R.G. Bonding of self-etching and totaletch systems to Er:YAG laser-irradiated dentin. Tensile bond strength and scanning electron microscopy. Braz. Dent. J. 2004, 15, SI-9-SI-20.

141. De Carvalho, R.C.R.; De Freitas, P.M.; Otsuki, M.; Eduardo, C.D.P.; Tagami, J. Micro-shear bond strength of Er:YAG-laser-treated dentin. Lasers Med. Sci. 2008, 23, 117-124. [CrossRef] [PubMed]

142. Chang, Y.E.; Shin, D.H. Effect of chlorhexidine application methods on microtensile bond strength to dentin in class i cavities. Oper. Dent. 2010, 35, 618-623. [CrossRef] [PubMed]

143. Dalkilic, E.E.; Arisu, H.D.; Kivanc, B.H.; Uctasli, M.B.; Omurlu, H. Effect of different disinfectant methods on the initial microtensile bond strength of a self-etch adhesive to dentin. Lasers Med. Sci. 2012, 27, 819-825. [CrossRef]

144. Davari, A.; Sadeghi, M.; Bakhshi, H. Shear Bond Strength of an Etch-and-rinse Adhesive to Er:YAG Laser- and/or Phosphoric Acid-treated Dentin. J. Dent. Res. Dent. Clin. Dent. Prospects 2013, 7, 67-73. [CrossRef] [PubMed]

145. Corona, S.A.M.; Atoui, J.A.; Chimello, D.T.; Borsatto, M.C.; Pecora, J.D.; Dibb, R.G.P. Composite resin's adhesive resistance to dentin: Influence of Er:YAG laser focal distance variation. Photomed. Laser Surg. 2005, 23, 229-232. [CrossRef]

146. Chiang, Y.S.; Chen, Y.L.; Chuang, S.F.; Wu, C.M.; Wei, P.J.; Han, C.F.; Lin, J.C.; Chang, H.T. Riboflavin-ultraviolet-A-induced collagen cross-linking treatments in improving dentin bonding. Dent. Mater. 2013, 29, 682-692. [CrossRef] [PubMed]

147. Sharma, V.; Kumar, S.; Rampal, P. Shear bond strength of composite resin to dentin after application of cavity disinfectants-SEM study. Contemp. Clin. Dent. 2011, 2, 155. [CrossRef]

148. Rayar, S.; Sadasiva, K.; Singh, P.; Thomas, P.; Senthilkumar, K.; Jayasimharaj, U. Department Effect of 2\% Chlorhexidine on Resin Bond Strength and Mode of Failure Using Two Different Adhesives on Dentin: An In Vitro Study. J. Pharm. Bioallied Sci. 2019, 11, S325-S330. [CrossRef]

149. Souza, F.B.; Silva, C.H.V.; Dibb, R.G.P.; Delfino, C.S.; Beatrice, L.C.S. Bonding performance of different adhesive systems to deproteinized dentin: Microtensile bond strength and scanning electron microscopy. J. Biomed. Mater. Res. Part B Appl. Biomater. 2005, 75, 158-167. [CrossRef]

150. Saboia, V.P.A.; Nato, F.; Mazzoni, A.; Orsini, G.; Putignano, A.; Giannini, M.; Breschi, L. Adhesion of a Two-step Etch-and-Rinse Collagen-depleted Dentin. J. Adhes Dent. 2008, 10, 419-422.

151. Hedayatollahnajafi, S.; Staninec, M.; Watanabe, L.; Lee, C.; Fried, D. Dentin bond strength after ablation using a CO 2 laser operating at high pulse repetition rates. Lasers Dent. XV 2009, 7162, 71620F. [CrossRef]

152. Ercan, E.; Erdemir, A.; Zorba, Y.O.; Eldeniz, A.U.; Dalli, M.; Ínce, B.; Kalaycioglu, B. Effect of Different Cavity Disinfectants on Bond Strength of a Posterior Composite. J. Adhes Dent. 2009, 11, 343-346. [CrossRef] [PubMed]

153. Stanislawczuk, R.; Da Costa, J.A.; Polli, L.G.; Reis, A.; Loguercio, A.D. Effect of tetracycline on the bond performance of etch-and-rinse adhesives to dentin. Braz. Oral Res. 2011, 25, 459-465. [CrossRef]

154. Reddy, M.S.C.; Mahesh, M.C.; Bhandary, S.; Pramod, J.; Shetty, A. Evaluation of effect of different cavity disinfectants on shear bond strength of composite resin to dentin using two-step self-etch and one-step self-etch bondingsystems: A comparative in vitro study. J. Contemp. Dent. Pract. 2013, 14, 275-280. [CrossRef] [PubMed]

155. Suma, N.K.; Shashibhushan, K.K.; Reddy, S. Effect of Dentin Disinfection with $2 \%$ Chlorhexidine Gluconate and $0.3 \%$ Iodine on Dentin Bond Strength: An in vitro Study. Int. J. Clin. Pediatr. Dent. 2017, 10, 223-228. [CrossRef] [PubMed]

156. Zabeu, G.S.; Maenossono, R.M.; Scarcella, C.R.; Brianezzi, L.F.F.; Palma-Dibb, R.G.; Ishikiriama, S.K. Effect of diode laser irradiation on the bond strength of polymerized nonsimplified adhesive systems after 12 months of water storage. J. Appl. Oral Sci. 2019, 27. [CrossRef]

157. Akturk, E.; Bektas, O.O.; Ozkanoglu, S.; Akin, E.G.G. Do Ozonated Water and Boric Acid Affect the Bond Strength to Dentin in Different Adhesive Systems? Niger. J. Clin. Pract. 2019, 22, 1758-1764. [CrossRef]

158. Ebrahimi-Chaharom, M.E.; Kimyai, S.; Mohammadi, N.; Oskoee, P.A.; Daneshpuy, M.; Bahari, M. Effect of sodium ascorbate on the bond strength of all-in-one adhesive systems to NaOCl-treated dentin. J. Clin. Exp. Dent. 2015, 7, e595-e599. [CrossRef]

159. Favetti, M.; Schroeder, T.; Montagner, A.F.; Correa, M.B.; Pereira-Cenci, T.; Cenci, M.S. Effectiveness of pre-treatment with chlorhexidine in restoration retention: A 36-month follow-up randomized clinical trial. J. Dent. 2017, 60, 44-49. [CrossRef]

160. Montagner, A.F.; Perroni, A.P.; Corrêa, M.B.; Masotti, A.S.; Pereira-Cenci, T.; Cenci, M.S. Effect of pre-treatment with chlorhexidine on the retention of restorations: A randomized controlled trial. Braz. Dent. J. 2015, 26, 234-241. [CrossRef]

161. Sartori, N.; Stolf, S.C.; Silva, S.B.; Lopes, G.C.; Carrilho, M. Influence of chlorhexidine digluconate on the clinical performance of adhesive restorations: A 3-year follow-up. J. Dent. 2013, 41, 1188-1195. [CrossRef]

162. Torres, C.R.G.; Barcellos, D.C.; Batista, G.R.; Pucci, C.R.; Antunes, M.J.S.; De La Cruz, D.B.; Borges, A.B. Five-year clinical performance of the dentine Deproteinization Technique in non-carious cervical lesions. J. Dent. 2014, 42, 816-823. [CrossRef] [PubMed]

163. Saboia, V.P.A.; Almeida, P.C.; Ritter, A.V.; Swift, E.J.; Pimenta, L.A.F. 2-Year clinical evaluation of sodium hypochlorite treatment in the restoration of non-carious cervical lesions: A pilot study. Oper. Dent. 2006, 31, 530-535. [CrossRef] [PubMed]

164. Akarsu, S.; Karademir, S.A.; Ertaş, S.A. The Effect of Diode Laser Application on Restoration of Non Carious Cervical Lesion: Clinical Follow Up. Niger J Clin Pr. 2020, 23, 165-171.

165. Dutra-Correa, M.; Saraceni, C.H.C.; Ciaramicoli, M.T.; Kiyan, V.H.; Queiroz, C.S. Effect of chlorhexidine on the 18-month clinical performance of two adhesives. J. Adhes. Dent. 2013, 15, 287-292. [CrossRef] [PubMed] 
166. ISO/TS 11405:2015 Dental Materials_Testing of Adhesion to Tooth Structure; International Organisation for Standardization: Geneva, Switzerland, 2015.

167. Secilmis, A.; Dilber, E.; Gokmen, F.; Ozturk, N.; Telatar, T. Effects of storage solutions on mineral contents of dentin. J. Dent. Sci. 2011, 6, 189-194. [CrossRef]

168. Santana, F.R.; Pereira, J.C.; Pereira, C.A.; Fernandes Neto, A.J.; Soares, C.J. Influence of method and period of storage on the microtensile bond strength of indirect composite resin restorations to dentine. Braz. Oral Res. 2008, 22, 352-357. [CrossRef]

169. Aydin, B.; Pamir, T.; Baltaci, A.; Orman, M.N.; Turk, T. Effect of storage solutions on microhardness of crown enamel and dentin. Eur. J. Dent. 2015, 9, 262-266. [CrossRef]

170. Tosun, G.; Sener, Y.; Sengun, A. Effect of storage duration/solution on microshear bond strength of composite to enamel. Dent. Mater. J. 2007, 26, 116-121. [CrossRef]

171. ISO 3696:1987-Water for Analytical Laboratory Use-Specification and Test Methods; International Organisation for Standardization: Geneva, Switzerland, 1987.

172. Coelho, A.; Paula, A.; Carrilho, T.; Silva, M.J.; Botelho, F.C.E. Chlorhexidine mouthwash as an anticaries agent-a systematic review. Quintessence Int. 2017, 48, 585-591.

173. Lim, K.S.; Kam, P.C.A. Chlorhexidine.-pharmacology and clinical applications. Anaesth Intensive Care 2008, 36, 502-512. [CrossRef] [PubMed]

174. Marsh, P.D.; Keevil, C.W.; McDermid, A.S.; Williamson, M.I.; Ellwood, D.C. Inhibition by the antimicrobial agent chlorhexidine of acid production and sugar transport in oral streptococcal bacterial. Arch. Oral Biol. 1983, 28, 233-240. [CrossRef]

175. Iwami, Y.; Schachtele, C.F.; Yamada, T. Mechanism of inhibition of glycolysis in Streptococcus mutans NCIV 11723 by chlorhexidine. Oral Microbiol. Immunol. 1995, 10, 360-364. [CrossRef] [PubMed]

176. Ximenes, M.; Cardoso, M.; Astorga, F.; Arnold, R.; Pimenta, L.A.; de S Viera, R. Antimicrobial activity of ozone and NaFchlorhexidine on early childhood caries. Braz. Oral Res. 2017, 31, 1-10. [CrossRef]

177. Nomura, R.; Inaba, H.; Matayoshi, S.; Yoshida, S.; Matsumi, Y.; Matsumoto-Nakano, M.; Nakano, K. Inhibitory effect of a mouth rinse formulated with chlorhexidine gluconate, ethanol, and green tea extract against major oral bacterial species. J. Oral Sci. 2020, 62, 206-211. [CrossRef]

178. Türkün, M.; Türkün, L.S.; Kalender, A. Effect of Cavity Disinfectants on the Sealing Ability of Nonrinsing Dentin-Bonding Resins. Yearb. Dent. 2006, 2006, 10-11. [CrossRef]

179. Zhou, J.; Tan, J.; Yang, X.; Xu, X.; Li, D.; Chen, L. MMP-Inhibitory effect of chlorhexidine applied in a self-etching adhesive. J. Adhes. Dent. 2011, 13, 111-115.

180. Osorio, R.; Yamauti, M.; Osorio, E.; Ruiz-Requena, M.E.; Pashley, D.; Tay, F.; Toledano, M. Effect of dentin etching and chlorhexidine application on metalloproteinase-mediated collagen degradation. Eur. J. Oral Sci. 2011, 119, 79-85. [CrossRef]

181. Montagner, A.F.; Sarkis-Onofre, R.; Pereira-Cenci, T.; Cenci, M.S. MMP Inhibitors on Dentin Stability: A Systematic Review and Meta-analysis. J. Dent. Res. 2014, 93, 733-743. [CrossRef]

182. Meiers, J.C.; Kresin, J.C. Cavity disinfectants and dentin bonding. Oper Dent. 1996, 21, 153-159.

183. Goncalves, M.; Corona, S.A.M.; Borsatto, M.C.; Pecora, J.D.; Dibb, R.G.P. Influence of pulse frequency Er:YAG laser on the tensile bond strength of a composite to dentin. Am. J. Dent. 2005, 18, 165-167. [PubMed]

184. Matsumotoa, K.; Hossain, M.; Tsuzuki, N.; Yamada, Y. Morphological and compositional changes of human dentin aftermEr:YAG laser irradiation. J. Oral Laser Appl. 2003, 3, 115-130.

185. Martínez-Insua, A.; Da Silva Dominguez, A.; Rivera, F.G.; Santana-Penín, U.A. Differences in bonding to acid-etched or Er:YAGlaser-trated enamel and dentin surfaces. J. Prosthet Dent. 2000, 84, 280-288. [CrossRef] [PubMed]

186. De Munck, J.; Van Meerbeek, B.; Yudhira, R.; Lambrechts, P.; Vanherle, G. Micro- tensile bond strength of two adhesives to Er:YAG-lased vs bur-cut enamel and dentin. Eur. J. Oral. Sci. 2002, 110, 322-329. [CrossRef] [PubMed]

187. Schein, M.T.; Bocangel, J.S.; Nogueira, G.E.C.; Schein, P.A.L. SEM evaluation of the interaction pattern between dentin and resin after cavity preparation using ER: YAG laser. J. Dent. 2003, 5712, 127-135. [CrossRef]

188. Büyükyilmaz, T.; Ogaard, B.; Rølla, G. The resistance of titanium tetrafluoride-treated human enamel to strong hydrochloric acid. Eur. J. Oral Sci. 1997, 105, 473-477. [CrossRef]

189. Hals, E.; Tveit, A.B.; Tötdal, B.; Isrenn, R. Effect of NaF, TiF4 and APF solutions on root surfaces in vitro, with specialreference to uptake of F. Caries Res. 1981, 15, 468-476. [CrossRef]

190. Wefel, J.S.; Harless, J.D. The effect of topical fluoride agents on fluoride uptake and surface morphology. J. Dent Res. 1981, 60, 1842-1848. [CrossRef]

191. Wiegand, A.; Magalhães, A.C.; Sener, B.; Waldheim, E.; Attin, T. TiF(4) and NaF at pH 1.2 but not at pH 3.5 are able to reduce dentin erosion. Arch Oral Biol. 2009, 54, 790-795. [CrossRef]

192. Arslan, S.; Ozbilge, H.; Kaya, E.G.; Er, O. In vitro antimicrobial activity of propolis, BioPure MTAD, sodium hypochlorite, and chlorhexidine on. Saudi Med. J. 2011, 32, 479-483.

193. Estrela, C.; Estrela, C.R.A.; Decurcio, D.A.; Hollanda, A.C.B.; Silva, J.A. Antimicrobial efficacy of ozonated water, gaseous ozone, sodium hypochlorite and chlorhexidine in infected human root canals. Int. Endod. J. 2007, 40, 85-93. [CrossRef] [PubMed]

194. Osorio, R.; Ceballos, L.; Tay, F.; Cabrerizo-Vilchez, M.A.; Toledano, M. Effect of sodium hypochlorite on dentin bonding with a polyalkenoic acid-containing adhesive system. J. Biomed. Mater. Res. 2002, 60, 316-324. [CrossRef] [PubMed] 
195. American Dental Association Council on Scientific Affairs Acceptance program guidelines: Dentin and enamel adhesive materials. Am. Dent. Assoc. Counc. Sci. Aff. Chicago Am. Dent. Assoc. 2001, 12, 1-12.

196. Gurgan, S.; Kiremitci, A.; Cakir, F.Y.; Gorucu, J.; Alpaslan, T.; Yazici, E.; Gutknecht, N. Shear bond strength of composite bonded to Er,Cr:YSGG laser-prepared dentin. Photomed. Laser Surg. 2008, 26, 495-500. [CrossRef] [PubMed]

197. Sterne, J.A.C.; Savović, J.; Page, M.J.; Elbers, R.G.; Blencowe, N.S.; Boutron, I.; Cates, C.J.; Cheng, H.-Y.; Corbett, M.S.; Eldridge, S.M.; et al. RoB 2: A revised tool for assessing risk of bias in randomised trials. BMJ 2019, 366. [CrossRef] [PubMed] 